\title{
A Techno-economic and Spatial Analysis for the Optimal Planning of Wind Energy in Kythira Island, Greece
}

\author{
Xydis, George
}

Published in:

International Journal of Production Economics

Link to article, DOI:

10.1016/j.ijpe.2013.02.013

Publication date:

2013

Link back to DTU Orbit

Citation (APA):

Xydis, G. (2013). A Techno-economic and Spatial Analysis for the Optimal Planning of Wind Energy in Kythira Island, Greece. International Journal of Production Economics, 146(2), 440-452.

https://doi.org/10.1016/j.ijpe.2013.02.013

\section{General rights}

Copyright and moral rights for the publications made accessible in the public portal are retained by the authors and/or other copyright owners and it is a condition of accessing publications that users recognise and abide by the legal requirements associated with these rights.

- Users may download and print one copy of any publication from the public portal for the purpose of private study or research.

- You may not further distribute the material or use it for any profit-making activity or commercial gain

- You may freely distribute the URL identifying the publication in the public portal

If you believe that this document breaches copyright please contact us providing details, and we will remove access to the work immediately and investigate your claim. 
A Techno-economic and Spatial Analysis for the Optimal Planning of Wind Energy in Kythira Island, Greece

George Xydis

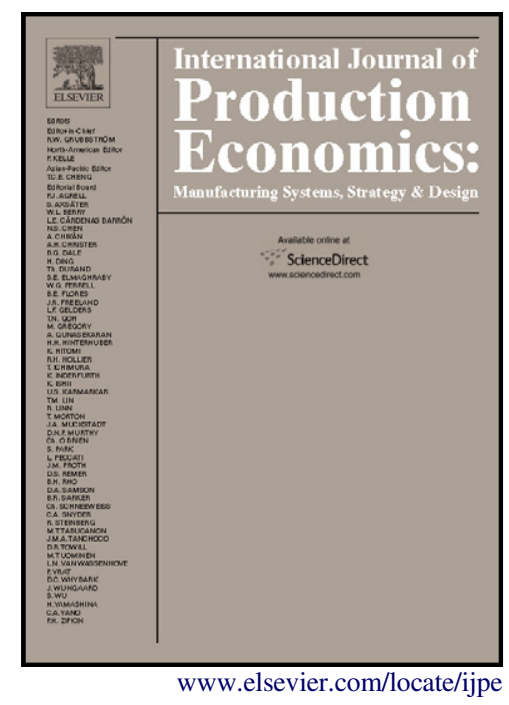

PII:

S0925-5273(13)00080-7

DOI: http://dx.doi.org/10.1016/j.ijpe.2013.02.013

Reference: PROECO5351

To appear in: Int. J. Production Economics

Received date: 20 March 2012

Revised date: 5 November 2012

Accepted date: 4 February 2013

Cite this article as: George Xydis, A Techno-economic and Spatial Analysis for the Optimal Planning of Wind Energy in Kythira Island, Greece, Int. J. Production Economics, http://dx.doi.org/10.1016/j.ijpe.2013.02.013

This is a PDF file of an unedited manuscript that has been accepted for publication. As a service to our customers we are providing this early version of the manuscript. The manuscript will undergo copyediting, typesetting, and review of the resulting galley proof before it is published in its final citable form. Please note that during the production process errors may be discovered which could affect the content, and all legal disclaimers that apply to the journal pertain. 


\title{
A Techno-economic and Spatial Analysis for the Optimal Planning of Wind Energy in Kythira Island, Greece
}

\author{
George Xydis \\ Technical University of Denmark, Dept. of Electrical Engineering \\ Frederiksborgvej 399, P.O.B. 49, Building 776, 4000 Roskilde \\ Tel.+4546774974, Email: gexy@elektro.dtu.dk; gxydis@gmail.com, Fax: \\ $+4546775688$
}

\begin{abstract}
Renewable Energy Sources (RES) and especially wind energy are seen as an essential part of the future clean energy system. In the present paper, the wind potential of Kythira Island was studied and a techno-economic analysis was done aiming at identifying the optimum solution for the proposed Wind Farms (WF) to be installed so that this isolated island to be interconnected to the mainland. The basic aim was to a) optimize the overall power output of the system, b) decrease the state participation investment costs, and c) secure energy safety for the area protecting at the same time the environment. For that reason, special focus was given to the environmental constraints for the implementation of a green development plan for the island. The detailed method followed was to examine different scenarios on wind farm optimal planning and taking into account environmental restrictions, the results of an
\end{abstract}


analytical investment tool and newly introduced indices help decision makers optimize the results. This study is a case study supporting an analyzing method that should be followed for all private investments which are subsidized partly from the state.

Keywords: Techno-economic Analysis, Interconnection, Wind Resource

\section{Nomenclature}

\begin{tabular}{|c|c|}
\hline$A$ & Depreciation \\
\hline AEPnet & Annual Energy Production net (MWh) \\
\hline$c$ & the windy (dimensionless) scale parameter \\
\hline$C_{i}$ & installed capacity of the under examination $W F(M W)$ \\
\hline$C D R$ & Capital Discount Rate \\
\hline$C L$ & $H V$ line estimated cost per $\mathrm{km}$ \\
\hline CVcoef & the conversion coefficient in current values ratio \\
\hline$C V F C F$ & Current Value Final Cash Flow \\
\hline$D m$ & deduction \\
\hline$d$ & rotor diameter \\
\hline$E q$ & other electrical electronic/mechanical Equipment costs \\
\hline$E x C F$ & Exergetic Capacity Factor \\
\hline$F N C F$ & Final Net Cash Flow \\
\hline FNI & Cumulative Cash Flow \\
\hline$f_{W e i(v)}$ & probability density function \\
\hline$i$ & Interest \\
\hline
\end{tabular}




\begin{tabular}{|c|c|}
\hline$I$ & interest of the loan \\
\hline$I C$ & Investment Cost \\
\hline Inst & Instalments \\
\hline IRR & Internal Rate of Return \\
\hline$k$ & the (dimensionless) shape parameter \\
\hline$l$ & the cable length [km] \\
\hline$L$ & Loan \\
\hline$M$ & Maintenance Costs \\
\hline$N P V$ & Net Present Value \\
\hline$N I$ & Net Income (or Net Cash Flow) \\
\hline$N R A$ & Net Repayment Amounts \\
\hline$O C$ & the total Operating Costs \\
\hline$O C F$ & Operating Cash Flow \\
\hline$P$ & the power load [kW] \\
\hline$P O$ & Personnel Operational Costs \\
\hline Pa-tax & Profits after-taxes \\
\hline$P p$-tax & Before Tax Earnings \\
\hline$R$ & the resistance in $[\mathrm{Ohm} / \mathrm{km}]$, \\
\hline$T_{0}$ & turnover (revenues) \\
\hline$T L$ & the transmission loss $[W]$ along the cable segment \\
\hline$U$ & the voltage level [kV] \\
\hline$U V$ & Unamortized Value \\
\hline$V$ & $\begin{array}{l}\text { land lease, administration costs, unexpected expenses or other } \\
\text { additional costs }\end{array}$ \\
\hline$W T_{\text {Ins }}$ & Insurance of Wind Turbines \\
\hline
\end{tabular}




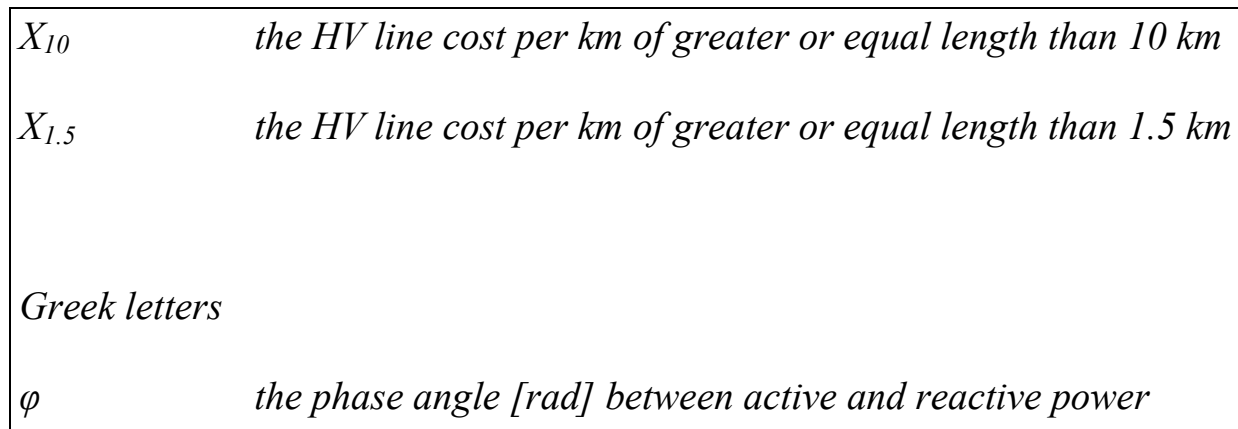

\section{Introduction}

An analytical methodology was presented in this paper to examine different WF planning options in a Greek Island based on environmental, economic and profitability criteria. Some new indices were introduced to assist decision makers optimize the results according not only to the growth of private funds but also based on the Greek welfare state. In order to reach the final results a detailed wind resource analysis, for analysing planning options is primarily needed.

Accurate wind resource measurements are necessary for the exploitation of wind energy, for identifying the wind power production potentiality of each area. For the evaluation and understanding of the prevailing winds in Kythira Island, Geographic Information Systems (GIS) tools, the WAsP (Wind Atlas Analysis and Application Program) [1] and WindRose [2] softwares were used as wind data analysis tools, and a wind map was created portraying the wind speed at a height of 80 meters above ground level (m.a.g.l.). 
Greek terrain is mostly mountainous with areas extending into the sea as peninsulas. For determining the wind profile in the islands different measuring and modelling techniques are used. However, more often - as in the examined case, meteorological masts are installed where this is possible. From the results' analysis an initial assessment of the under examination area is the outcome each time. In this paper, initially, a complete statistical analysis of the wind data and a wind turbine planning/sitting (taking into consideration all the planning and environmental constraints) on the island was done and based on the up-to-date interconnection costs a techno-economic analysis helps to finalize the WF planning and the size of the investment. A literature review, site experimental results, discussion and conclusions follow in the next sections. This first section is the introduction; section 2 includes important background studies on the field, section 3 presents the methodology, section 4 examines different scenarios and section 5 concludes.

\section{Literature Review}

A large body of literature concerning the interconnection of insular areas with the main system worldwide has been carried out over the past few decades. Not many however deal with the interconnection of the Greek Islands with the mainland. Hatziargyriou et al. [3] showed how the Islands' interconnection will contribute to increase the wind power penetration in the Greek system. The authors examined planning constraints in the Cyclades prefecture and how, through the use of interconnection grids, the favourable wind conditions could be exploited. Georgiou et al. [4] examined the effect of the Islands' interconnection to the Greek power sector. Their extensive analysis showed that RES are highly essential as their break in the 
power production mix is possible to reach $56 \%$ of the total electricity demand. Since 2005, the studies from Papadopoulos et al. [5 - 6], and Karamanou et al. [7], the updated strategic study on the interconnection of Greek Islands from the Institute of Communication and Computer Systems [8], and lately the study for the interconnection of Crete with the mainland [9] predicates the academic and intensifies the commercial interest for the exploitation of the dominant wind power of the Greek Islands. The above mentioned studies [5 - 9] examine different scenarios regarding their connection with the mainland. Grouping islands and defining interconnection schemes, setting the limits (constraints) for the different seasonal load on a long-term basis lead to important conclusions about the interconnection of the Aegean Islands.

A larger body of recent papers and studies regarding the application of wind resource assessment in insular or remote areas worldwide has been carried out. Palaiologou et al. [10] performed a statistical analysis followed by a power production analysis and a power map production in the Island of Lesvos. Prasad et al. [11] studied the power density for Vadravadra site in Fiji Islands, while Segurado et al. [12] where based on the $\mathrm{H}_{2}$ RES computer model, the integration of renewable sources and hydrogen in the Island's energy system was simulated. Several scenarios were examined and the maximization of renewable energy in this grid resulted in a percentage of $33 \%$, focusing mainly on wind. Liu and Wu [13] proposed that renewable energy shall reach a $34 \%$ of the electricity consumption in Kinmen Island by 2020 . Kaldellis et al. [14] studied and dimension a wind-based pumped hydro storage system for the island of Lesbos. Nandi and Ghosh [15] did a techno-economical analysis of off-grid hybrid systems at Kutubdia Island. They used the NREL simulation software HOMER and after they did wind and solar resource analysis they suggested the use of hybrid 
energy systems in order to reduce the fuel consumption. They concluded that winddiesel hybrid systems based on the island's needs are more cost effective compared to wind-alone, PV-alone systems and wind-PV hybrid system. Giatrakos et al. [16] also used HOMER simulation tool based on different scenarios (a. 20\% RES penetration, b. $20 \%$ RES adding hydrogen for transport, c. $100 \%$ RES via hydrogen storage) to result to the best solution for maximizing RES penetration in Karpathos Island. Darus et al. [17] designed a hybrid (wind and solar system) for sustainable living at Perhentian Island in Malaysia while Dua et al. [18] implements a feasibility study for the Fox Islands examining closely the viability potential for the future wind energy growth.

However, there is not a detailed study in the literature that links the need for wind energy in an isolated area in order to take advantage the dominant wind speed on that area and the interconnection costs with the mainland and the. This paper is a unique case study since it deals with an island close to the shore $(17 \mathrm{~km})$ with extremely good wind conditions and can actually be seen as a part of the mainland system or just as an isolated system (covering only the island's energy needs). A detailed flowchart of the analytical evaluation process and the analytical investment tool can be seen in figure 1. 


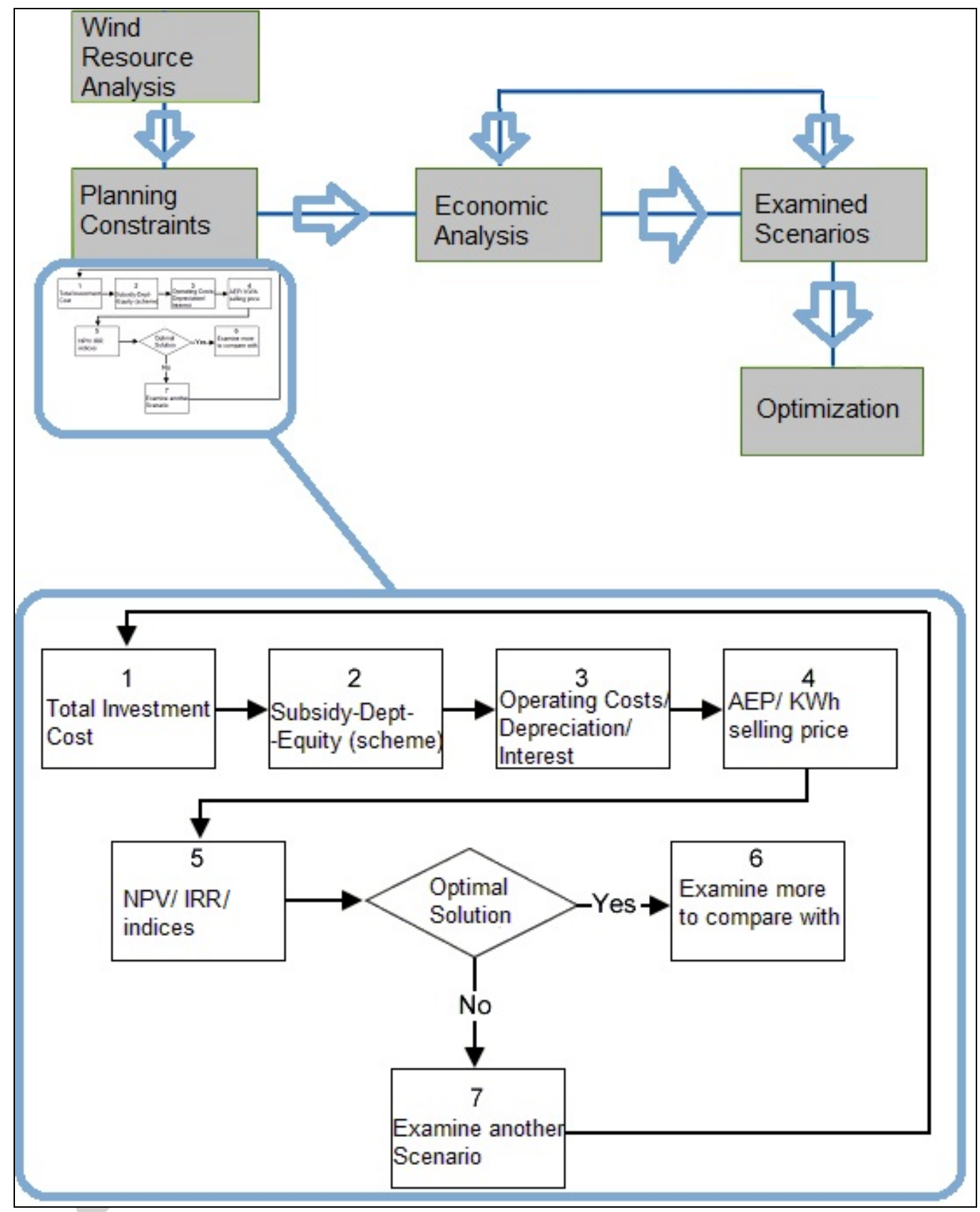

Figure 1. A detailed flowchart of the proposed evaluation methodology and the investment tool

\section{Proposed methodology}

\subsection{Site Experimental Results - Statistical Analysis}


Kythira Island lies opposite the eastern edge of the Peloponnese peninsula (Capo Maleas). The island's area is about $280 \mathrm{~km}^{2}$. The form of the terrain with shaped shores into steep cliffs is a result of the prevailing winds in the wider area. Wind profile measurements were carried out for specific periods using a meteorological mast close to the existing Radar close to the highest mountain on the west called Mermigkaris (Figure 2).

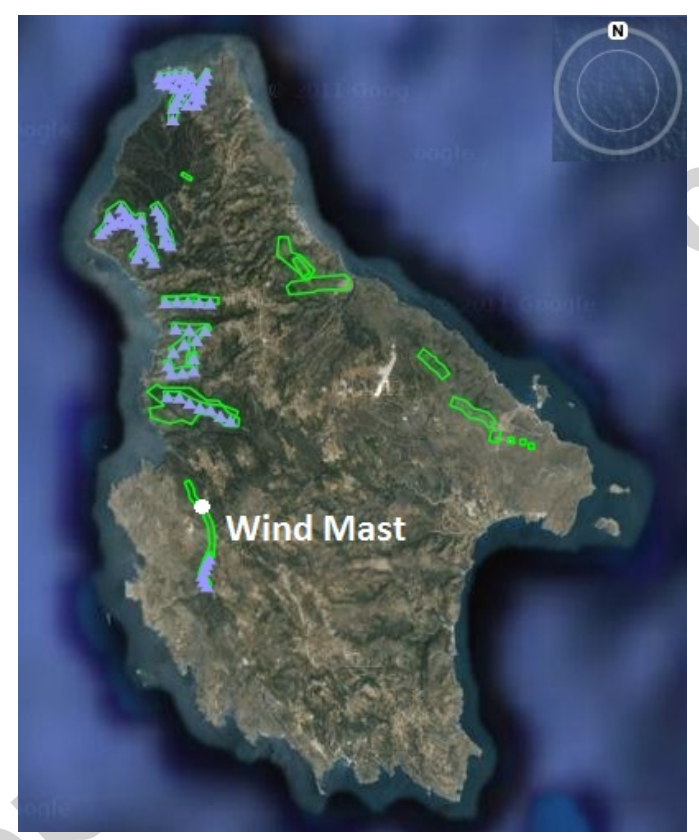

Figure 2. The installed mast on the Kythira Island and the WF applications

Mast coordinates, average speed, period of measurement, height in meters above ground level, and temperature are shown on Table 1. The tools used for elaborating the annual measurements and produce estimates of wind speed/energy output (at various distances from the measuring meteorological mast) were WindRose [2] and WAsP softwares [1]. Vector Hellenic Windfarms S.A. operates a certified laboratory (Laboratory of Wind Measurements) from Hellenic Accreditation System S.A. 
(E.SY.D.) in Greece and the meteorological stations were under the laboratory's supervision.

Table 1. Main measured characteristics of the wind mast

\begin{tabular}{|c|c|c|c|c|c|}
\hline $\begin{array}{l}\text { Latitude } \\
\left(^{\circ}\right)\end{array}$ & $\begin{array}{l}\text { Longitude } \\
\left(^{\circ}\right)\end{array}$ & $\begin{array}{c}\text { Mean speed } \\
\left(\mathrm{m} \cdot \mathrm{s}^{-1}\right)\end{array}$ & $\begin{array}{l}\text { Period of } \\
\text { data analysis }\end{array}$ & $\begin{array}{l}\text { Height } \\
\text { (magl) }\end{array}$ & $\begin{array}{c}\text { Av. Turbulence } \\
\text { Intensity (at 10m.) }\end{array}$ \\
\hline $36^{\circ} 13^{\prime} 45.67^{\prime \prime} \mathrm{N}$ & $22^{\circ} 56^{\prime} 27.33^{\prime \prime} \mathrm{E}$ & $\begin{array}{l}8.22 \text { at } \\
20 \mathrm{~m} .\end{array}$ & $\begin{array}{c}22 \text { Oct '07-22 } \\
\text { Oct '08 }\end{array}$ & 470 & $11.137 \%$ \\
\hline
\end{tabular}

It is easily noticeable just by reviewing the wind rose (figure 3 ) that the two main directions (primary and secondary direction) were ESE and SE respectively however a significant portion is NNW and $\mathrm{W}$.

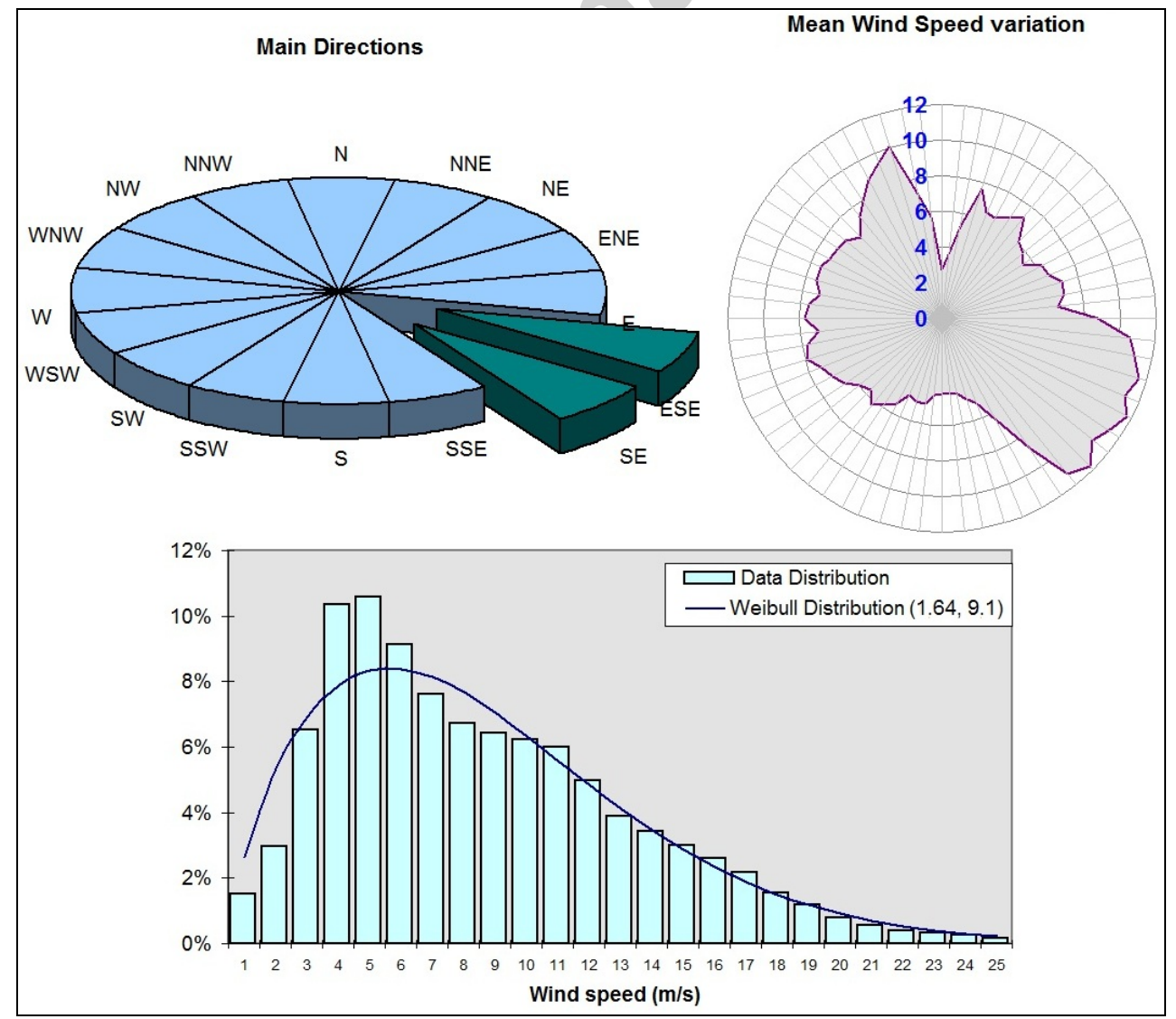


Figure 3. Wind Rose of the Mast of Kythira Island and Data and Weibull Distribution

The wind was studied for one (1) year from 22 Oct. 2007 to 22 Oct. 2008. A 20 m. mast was installed made out of steel in tubular form kept in vertical position using tense wires. Anemometers and vanes were placed every ten meters $(10 ; 20)$. A data logger connected to the available sensors of the mast stored and sent the data to the responsible laboratory using the GSM method. The required power for the above mentioned instruments was provided by $12 \mathrm{~V}$ batteries, charged by a PV panel. The uncertainty of the measured wind speed for the mast was calculated using the WindRose software [2] at $0.115 \mathrm{~m} / \mathrm{s}$. The maximum $10 \mathrm{~min}$ average speed observed was $31.14 \mathrm{~m} / \mathrm{s}$ and the maximum gust $39.92 \mathrm{~m} / \mathrm{s}$.

A preliminary statistical analysis of the measurements was useful for identifying the relationships among the examined variables. Weibull and Rayleigh probability density functions analyses which have an acceptable accuracy level by many wind resource studies in different locations [19-24] were used to identify the representation of the wind speed frequency curve.

In Weibull distribution, the probability density function and the cumulative distribution indicates the variation in wind velocity. The probability density function $f_{W e i}(v)$ is given from the following equation:

$$
f_{W e i}(v)=\frac{k}{c} \cdot\left(\frac{v}{c}\right)^{k-1} \cdot e^{-(v / c)^{k}}
$$

where $k$ is the (dimensionless) shape parameter showing how peaked the wind distribution is, and $c$ is the windy (dimensionless) scale parameter. $k$ and $c$ must be 
calculated using the Weibull probability plotting paper method. The cumulative distribution function is transformed into a linear form, adopting logarithmic scales and as the wind velocity is equal or lower than $v$ we get:

$$
\ln \left\{-\ln \left[1-f_{W e i}(v)\right]\right\}=k \cdot \ln (v)-k \cdot \ln c
$$

If we plot that in axes $\ln (v)$ in $\mathrm{X}$ and $\ln \left\{-\ln \left[1-f_{W e i}(v)\right]\right\}$ in $\mathrm{Y}$, then the Weibull distribution is a straight line, with a slope of which is $k$ and intersection $-k \cdot l n c$. The real values of $k$ and $c$ can be found by producing the regression equation for the plotted line. It is known that for most wind conditions $k$ ranges from 1.5 to 3 , while $c$ ranges from 3 to 8 [25]. The results from the data and the Weibull distribution shown in figure 3 and in table 2, the Weibull shape and scale, the data distribution, the mean wind speed and the Turbulence Intensity (T.I.) at $10 \mathrm{~m} / \mathrm{s}$ are shown for each direction.

Table 2. Weibull distribution analysis of Kythira Island mast

\begin{tabular}{|r|r|r|r|r|r|r||}
\hline Direction & Angles (deg) & Weibull & Weibull & Data & Mean Wind & T.I. at \\
& & shape & scale & Distrib & Speed (m/s) & 10m/s \\
\hline NNE & $11.25-33.75$ & 1.78 & 7.18 & $0.55 \%$ & 6.5 & 9.3 \\
\hline NE & $33.75-56.25$ & 1.61 & 6.76 & $1.14 \%$ & 6.2 & 9.3 \\
\hline ENE & $56.25-78.75$ & 2.21 & 7.37 & $2.92 \%$ & 6.6 & 9.4 \\
\hline E & $78.75-101.25$ & 1.86 & 10.83 & $11.86 \%$ & 9.4 & 10.2 \\
\hline ESE & $101.25-123.75$ & 1.94 & 12.99 & $12.94 \%$ & 11.4 & 10.0 \\
\hline SE & $123.75-146.25$ & 2.34 & 12.49 & $12.18 \%$ & 11.1 & 10.4 \\
\hline SSE & $146.25-168.75$ & 1.54 & 6.11 & $3.66 \%$ & 5.7 & 11.3 \\
\hline S & $168.75-191.25$ & 1.47 & 4.29 & $3.38 \%$ & 4.3 & 14.3 \\
\hline \hline SSW & $191.25-213.75$ & 1.51 & 5.44 & $4.03 \%$ & 5.1 & \\
\hline
\end{tabular}




\begin{tabular}{|r|r|r|r|r|r|r||}
\hline SW & $213.75-236.25$ & 1.99 & 6.66 & $7.18 \%$ & 5.9 & 19.4 \\
\hline $\mathbf{W S W}$ & $236.25-258.75$ & 1.91 & 8.26 & $12.23 \%$ & 7.4 & 13.8 \\
\hline $\mathbf{W}$ & $258.75-281.25$ & 1.73 & 8.07 & $10.14 \%$ & 7.3 & 10.8 \\
\hline $\mathbf{W N W}$ & $281.25-303.75$ & 1.37 & 7.78 & $7.45 \%$ & 7.2 & 8.8 \\
\hline $\mathbf{N W}$ & $303.75-326.25$ & 1.51 & 7.63 & $5.44 \%$ & 7.0 & 9.2 \\
\hline $\mathbf{N N W}$ & $326.25-348.75$ & 1.97 & 10.36 & $4.46 \%$ & 9.1 & 9.2 \\
\hline \hline $\mathbf{N}$ & $348.75-11.25$ & 1.43 & 5.46 & $0.44 \%$ & 4.4 & 10.0 \\
\hline
\end{tabular}

\subsection{Wind Resource Analysis}

The total number of valid data used was 52,654 (missing data $0.4 \%$ ) and the included number of calms $(<2 \mathrm{~m} / \mathrm{s})$ was 2,367 . Based on the data, the WAsP software was used to produce a wind map of the area (Figure 4). The estimated wind speed could be visualized and different sites for WFs could be selected and proposed to be developed. After the wind analysis implemented in the area (Figure 4) the results show that the lowest average wind speed is $4.13 \mathrm{~m} / \mathrm{s}$ and the highest is $11.75 \mathrm{~m} / \mathrm{s}$. This shows that in the island, even sites at low altitude or at sea level seem to present an exploitable profile. Because of that, many wind project developer companies and utilities have shown a clear interest on the wind energy exploitation of the area. 


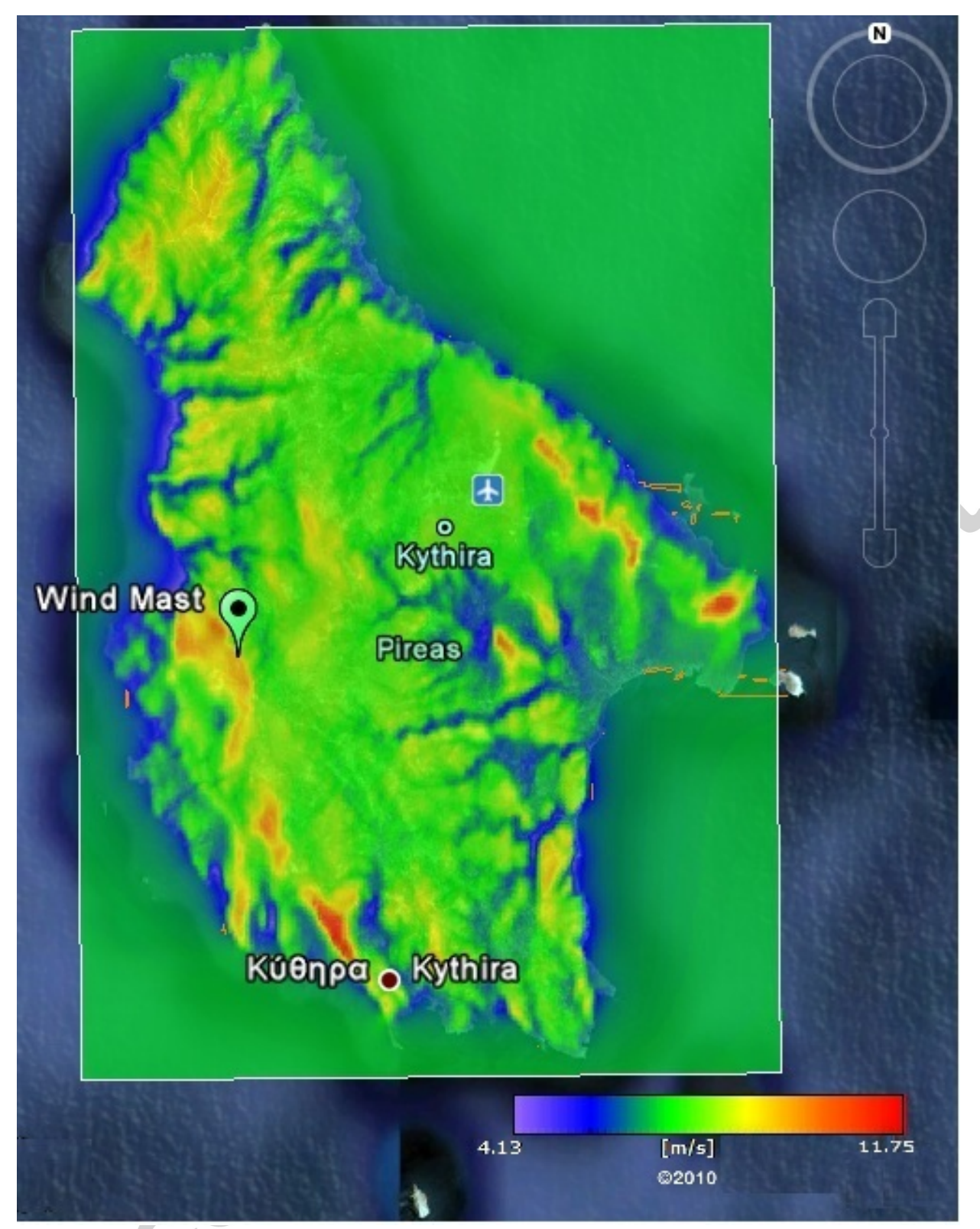

Figure 4. Wind resource analysis in the Kythira Island

Based on the Regulatory Authority for Energy (RAE) files, on the application files for power production licensing for new projects [26], 322.15 MW have been proposed (submitted) to be installed in the island (figure 2). Are all these necessary for the system? Are all environmentally approved? What the least cost to High Voltage Direct Current (HVDC) interconnect Kythira Island with the shore and then to the 
closest substation? What is the most effective and at the same time least costly scenario?

\section{Economic Analysis - Scenarios}

The Greek State, following the general guidelines of the EU, encourages - as in other EU countries - the implementation of Renewable Energy projects by private funds. In specific every RES project owner can apply for subsidization and be supported on the basis of the well known Feed-in-Tariff (FiT) financing scheme under the frames of the development law [27]. The FiT mechanism used in other countries as well [2829] in order to support the RES-based units electricity provided to the grid. A fixed

price per kWh payment - on the basis of Power Purchase Agreements (PPAs) signed among the Independent Power Producer (IPP) the Hellenic Transmission System Operator (HTSO) and the Public Power Corporation (PPC) - for electricity generated by a renewable resource is assured and annually readjusted following the official suggestion of the RAE [30].

For that reason an analytical investment tool was developed and used for this study, and different scenarios were examined for the evaluation and proper exploitation of wind energy on the island.

The energy yield of a WF is usually expressed via the following:

AEPnet $=8760 \cdot C i \cdot E x C F$, 
where 8760 are the total hours within a year, $C i$ the installed capacity of the under examination WF in MW and $\operatorname{ExCF}(0 \leq E x C F \leq 1)$ is the Exergetic Capacity Factor as in [31] and [32] it explains better the meaning of the real capacity factor of the WF in the means of the actual use of energy. The Exergetic Capacity Factor includes all topographic and wake losses, electrical losses, wind turbine technical availability losses, and air density losses.

\subsection{WF Cost Model-Cash Flow}

The turnover (revenues) $T_{0}$ for the total of the 20 years of the contract of the WF are:

$$
\sum_{y r=1}^{y r=20} T_{0}=\text { AEPnet } \cdot \text { FiT }
$$

where FiT is being redefined every year according to a decision of RAE.

Based on the current legislation (Law 3851/2010 "Accelerating the development of Renewable Energy Sources to deal with climate change and other regulations addressing issues under the authority of the Ministry of Environment, Energy and Climate Change"), an amount up to $1 \%$, before V.A.T., on the selling price of the electrical energy from R.E.S. is transferred to household consumers through the bills for electrical energy consumption and an amount of $0.3 \%$ on the before V.A.T., selling price of the electrical energy from R.E.S. is passed to the Special Fund for the implementation of Regulatory and Environmental Plans. The rest (up to 3\%) goes to the local municipalities. This total $3 \%$ deduction $D m$ is defined as: 


$$
\sum_{y r=1}^{y r=20} D m=3 \% \cdot \sum_{y r=1}^{y r=20} T_{0}
$$

Other major costs are Personnel Operational Costs, PO, Maintenance Costs, $M$, Insurance of Wind Turbines, $W T_{\text {Ins }}$, other electrical electronic/mechanical Equipment costs, $E q$, land lease, administration costs, unexpected expenses or other additional costs, $V$. Therefore, the total Operating Costs, $O C$, are:

$$
\sum_{y r=1}^{y r=20} O C=\sum_{y r=1}^{y r=20} D_{m}+\sum_{y r=1}^{y r=20} P O+\sum_{y r=1}^{y r=20} M+\sum_{y r=1}^{y r=20} W T_{I n s}+\sum_{y r=1}^{y r=20} E q+\sum_{y r=1}^{y r=20} V
$$

where $P O$ are the salaries for the permanent employees of the WF during operation period (after construction till the end of life of the farm which is 20 years), $M$ the required extension cost to be paid to the wind turbines manufacturers (fixed price most of the times per MW or turbine) in order the service to be undertaken from them, $W T_{\text {Ins }}$ a standard percentage based on the WFs total investment initial cost.

The proposed financial plan usually for a project is Equity: $25 \%$, Dept: $35-45 \%$ (full repayment period is set to be 10 years, with standard sinking fund and depending on the market rules a loan interest could be between $6-7 \%$ ), and subsidy: $30-40 \%$, depending of course on the size of the company and the prefecture that the project is proposed to be installed (there are amplifying mechanisms for the isolated areas that increase the state subsidization). It is necessary however, the proposed financial scheme to cover the minimum requirements in equity capitals set by the development law of $25 \%$ [27]. 
Regarding the Operating Cash Flow, $O C F$ :

$$
\sum_{y r=1}^{y r=20} O C F=\sum_{y r=1}^{y r=20} T_{0}-\sum_{y r=1}^{y r=20} O C
$$

Taking into consideration that usually a private equity and dept ought to be fully be re-paid (depending on the subsidization) a $60-70 \%$ of the total Investment Cost, IC is the participation rate out of all. Therefore for the Unamortized Value, $U V$ :

$$
\sum_{y r=1}^{y r=20} U V=a \cdot I C, \text { where } 0.6 \leq a \leq 0.7
$$

The Depreciation, $A$, can be estimated using the formula:

$$
\sum_{y r=1}^{y r=20} A=15 \% \cdot \sum_{y r=1}^{y r=20} U V \text { where } 15 \% \text {, the depreciation declining balance method, }
$$

After calculating the payment amount (Instalments Inst) on the Loan, $L$, assuming the rate of Interest, $i$, following the formula:

$$
\sum_{y r=1}^{y r=10} \operatorname{Inst}=\sum_{y r=1}^{y r=10}(L \cdot i) /[1-(1+i)]^{-N}
$$

where $\mathrm{N}(=10)$ the years of repayment and after calculating the interest of the loan $I$ 


$$
\sum_{y r=1}^{y r=20} I=i \cdot \sum_{y r=1}^{y r=20} L
$$

and update the calculations, on a yearly basis, based on the loan balance update. Therefore, Before Tax Earnings, $P p$-tax, are given from:

$$
\sum_{y r=1}^{y r=20} P_{p-t a x}=\sum_{y r=1}^{y r=20} O C F-\sum_{y r=1}^{y r=20} A-\sum_{y r=1}^{y r=10} I
$$

Also, knowing that the taxes for WF investments are 25\% the final results (Profits after-taxes, $P$ a-tax $)$ can be estimated by removing the taxes from $P p$-tax. This way Net Income (or Net Cash Flow) NI is equal to:

$$
\sum_{y r=1}^{y r=20} N I=\sum_{y r=1}^{y r=20} P_{a-t a x}+\sum_{y r=1}^{y r=20} A,
$$

and Final Net Cash Flow, FNCF:

$$
\sum_{y r=1}^{y r=20} F N C F=\sum_{y r=1}^{y r=20} N I-\sum_{y r=1}^{y r=20} N R A,
$$

Where NRA the Net Repayment Amounts. Calculating the Cumulative Cash Flow (adding up for all 20 years the $F N I$ ) and the conversion coefficient in current values ratio, CVcoef, using the formula: 


$$
C V_{\text {coef }}=\frac{1}{(1+C D R)^{y r}}
$$

Where $C D R$ is the Capital Discount Rate and $y r$ each year, the Current Value Final Cash Flow, $C V F C F$, can be calculated from:

$$
\sum_{y r=1}^{y r=20} C V F C F=C V_{c o e f} \cdot \sum_{y r=1}^{y r=20} F N C F
$$

which gives us the Net Present Value (NPV), the project repayment period (when the cash flow turns to positive), the Cumulative Revenues and finally the Project IRR. The project IRR is the discount rate that makes the NPV of all cash flows of the project equal to zero.

\subsection{Constraints}

In Kythira Island the scenarios based on the above mentioned WF Cost Model can be specified and by following a "wind symbiosis" study, the maximum of the wind available for exploitation shall be revealed. The basic aim was to select different sites within the under examination area and estimate weather these sites were promising for WF development or not based on the existing constraints. Small villages located in the island and at the same time the interesting wind speed results make necessary the need for such a plan. A GIS-based methodology was used for the preliminary evaluation of the area. Taking into consideration planning constraints based on the Special Framework for Spatial Planning of Renewable Energy [33], and the Law 3851/2010 for accelerating the development of RES [34], as villages near the area, monasteries, 
archaeological sites, isolated buildings, Natura 2000 areas, Special Protected Areas (SPA), archaeological sites, important coasts and beaches, even roads, the necessary distances were kept and the available sites of possible wind development interest remained.

The area is of some archaeological interest. Furthermore, over the last decades the touristic development is observed mainly because of a beachfront villages and beaches. Therefore, there are a lot of constraints to be placed on a map and therefore the sites available for exploitation to be revealed. Based on the Special Framework for Spatial Planning of Renewable Energy [33], there are different safety distances that should be kept prior the final sitting of a WF. For instance, it's 1,500 m. from traditional villages (500 m. from every other village), at least 3,000 m. from important archaeological sites, 1,000 m. from organized touristic areas, $500 \mathrm{~m}$. from excavating zones, $1.5 \mathrm{x} d$ from roads (class 3 ) and railways, where $d$ equals the diameter of the proposed wind turbine.

All geographical constraints for the development of any industrial project (including WFs) are shown on figure 5. In a scaled 1:50,000 map are shown graphically all restrictions as residential zones, Sites of Community Interest (SCI), SPAs, traditional villages, archaeological sites, Radars, main roads, Airport and the $12^{\circ}$ angle limit on the extension for the airport lane, waste disposal areas etc. 


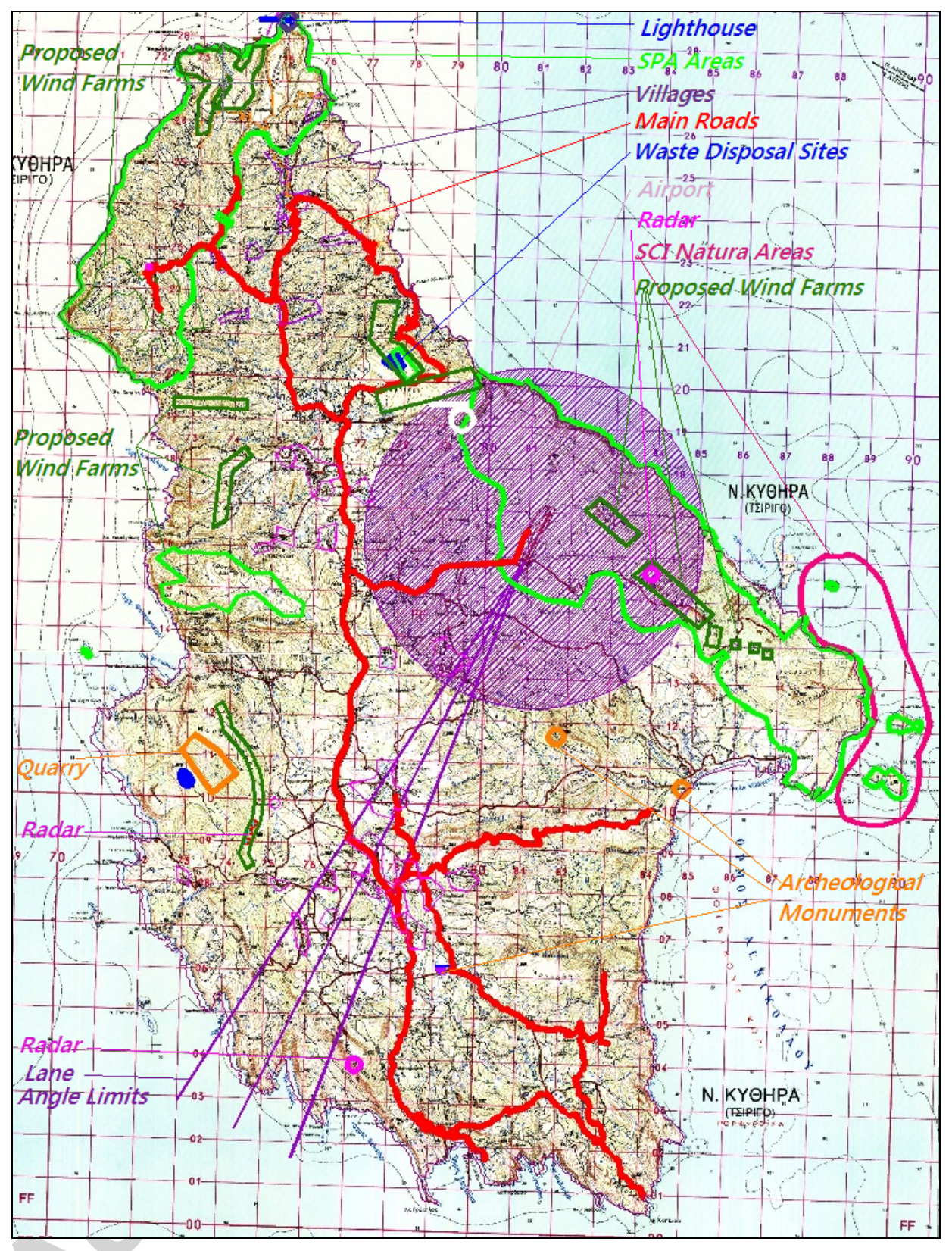

Figure 5. Kythira Island topographical map 1:50,000 including constraints

Apart from those limitations shown on the map, all the above mentioned distancebased, based on the Special Framework for Spatial Planning of Renewable Energy, were taken into consideration.

\subsection{Examined Scenarios}


For the planning, the proposed wind turbines to be used by the project developers were ENERCON E82-2.0 MW and VESTAS V90-3.0 MW, based primarily on the wind classification restrictions [35]. Apart from the wind turbine costs other major costs are the civil engineer works (road construction works, excavations etc), interconnection costs (WFs internal connection with Medium Voltage (MV) cables, substation, High Voltage Alternating Current (HVAC) cables and interconnection with the Public Power Coorporation (PPC) grid, submarine HVAC cable), and other transportations to the installation areas. The distance to the shore connecting the island with the mainland is $20 \mathrm{~km}$ and a TKRA $170 \mathrm{kV} 3 \times 400 \mathrm{~mm}^{2}$ will be needed. The distance from the shore to the planned PPC substation in Neapolis is $12 \mathrm{~km}$. The maximum sea depth on the offshore route is $270 \mathrm{~m}$.

The main costs taken into consideration for this study are the WFs internal MV interconnection, the submarine cable and the $12 \mathrm{~km} \mathrm{HV}$ cable to the grid substation. Based on the wind farm results and costs several scenarios were examined.

It's rather clear that from the remaining areas only few of them, following the applications of the wind developers in the Kythira Island can be exploited based on the wind results. It was found that at maximum $122 \mathrm{MW}$ do not "concur" on some constraint and could be possibly developed and since a detailed wind resource analysis $(50 \times 50 \mathrm{~m}$.) was implemented in the previous section, a draft estimation of the power output of the wind farms could be done (Table A1 - Appendix). The spatial distribution of the proposed WFs and the substations are shown on the power density map of the Kythira Island (Figure 6). In this scenario, a preliminary design of the 
proposed WFs was done and the internal and external cable routes (for the MV these routes will follow the roads for the transportation) were drawn in order to identify the length of the needed cabling. For the internal MV grid there will be needed $4 \mathrm{~km}$ for the $1^{\text {st }}$ group of WFs, $10 \mathrm{~km} \mathrm{MV} \mathrm{for} \mathrm{the} 2^{\text {nd }}$ group of WFs and $2 \mathrm{~km}$ for the $3^{\text {rd }} \mathrm{WF}$ (figure 6). For the external interconnection till the substations $18 \mathrm{~km} \mathrm{MV}$ for the $3^{\text {rd }}$ WF, $10 \mathrm{~km}$ of $\mathrm{HV}$ cable to get from the lower substation to the upper substation and 6 $\mathrm{km}$ of HV cables for the $1^{\text {st }}$ group of the WFs to be transferred to the upper substation. Furthermore, for the whole project $19 \mathrm{~km}$ of submarine cable and another $10 \mathrm{~km}$ to get to the PPC substation and connect with the grid in the mainland. The positions of the substations were selected under i) the metacentre principle/concept of the power generated, ii) the need also for the produced electricity to be transferred to the mainland avoiding building the upper substation in the SPA area on the northern side of the island and at the same time iii) trying as much as possible to shorten the submarine cable needed to the shore due to its significant cost (Figures 4, 5). 


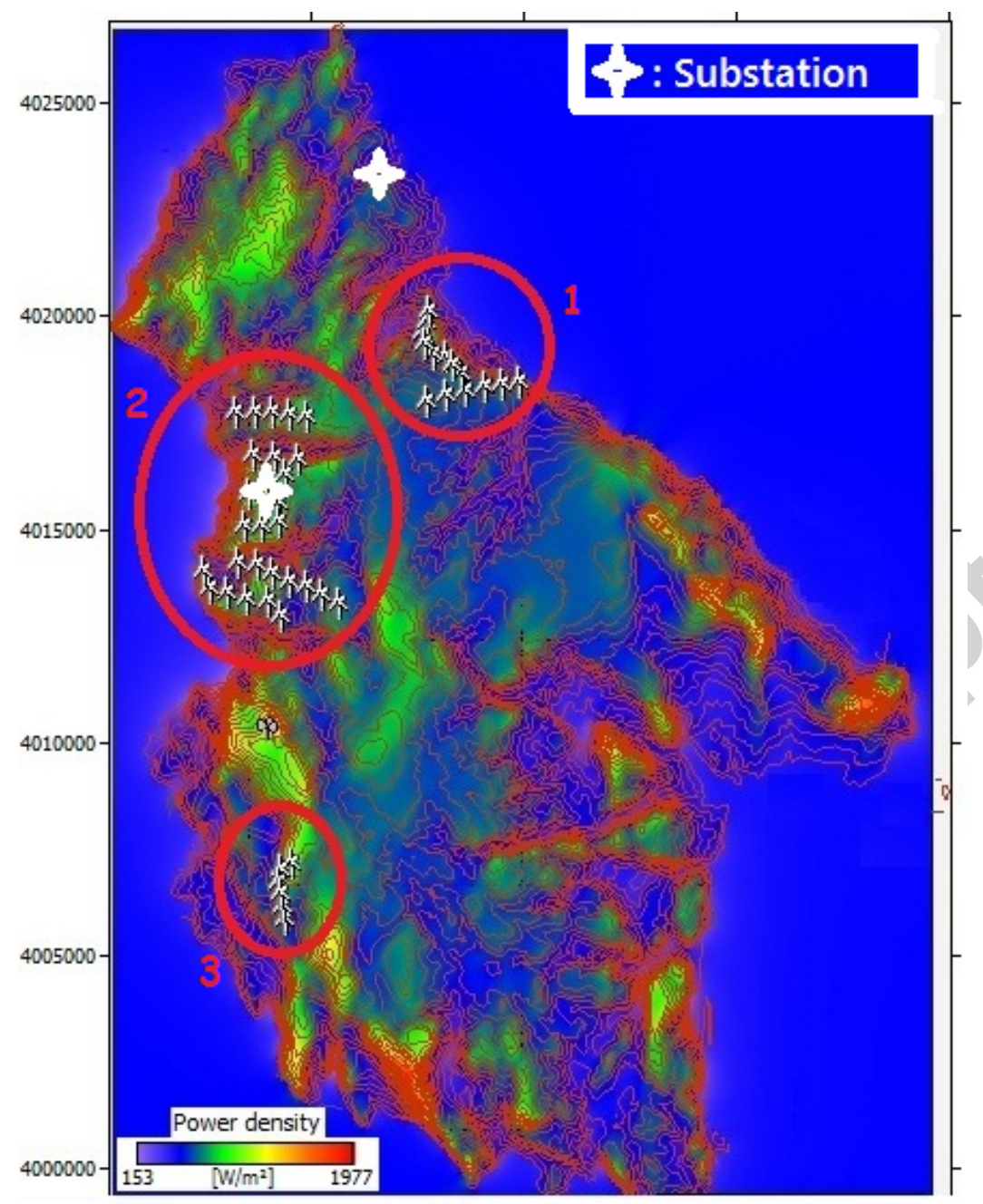

Figure 6. Kythira Island power density map and the $122 \mathrm{MW}$ most likely scenario to go on.

The costs for the interconnection of the Kythira Island were taken from RAE's study for the Consent of the Interconnection to the Transmission System study [36].

The interconnection losses were calculated based on the above mentioned study but also based on [37] from the formula:

$T L=k \cdot P^{2}$, 
where $k=\frac{R \cdot l}{U^{2}} \cdot\left(1+\tan ^{2} \phi\right)$.

$T L$ represents the transmission loss $[\mathrm{W}]$ along the cable segment; $P$ is the power load $[\mathrm{kW}] . R$ is the resistance in $[\mathrm{Ohm} / \mathrm{km}], l$ the cable length $[\mathrm{km}], \varphi$ the phase angle $[\mathrm{rad}]$ between active and reactive power and $U$ the voltage level $[\mathrm{kV}]$.

According to RAE's study [36], the estimated cost per km, $C L$, of a HV line between 1.5 and $10 \mathrm{~km}$ is given based on the formula:

$\left.C L=X_{10} \cdot[1+(10-l)] \cdot \frac{X_{1.5}-X_{10}}{8.5 \cdot X_{10}}\right]$

where $X_{10}$ the HV line cost per km of greater or equal length than $10 \mathrm{~km}$ and $X_{1.5}$ the $\mathrm{HV}$ line cost per $\mathrm{km}$ of greater or equal length than $1.5 \mathrm{~km}$ according to Table A2 (Appendix). Regarding the costs for the MV cables, they were estimated from the connection offers from the Hellenic Transmission System Operator (HTSO) [38], while for the wind turbine costs, submarine cable, the estimated cost was taken after personal contact of the author with wind project developers [39], [40]. Also, based on the Law 3851 [34], new submarine interconnection necessary to drive produced energy to the grid could be subsidized according to the formula:

$$
\psi=10 \%+\sqrt{\frac{l}{10 \cdot C i}} \%,
$$


where $l$ is the length of the submarine cable and $C i$ the proposed installed capacity of the Wind Farms. Based on a typical wind farm cost breakdown analysis [41] as well, the economic results for all the scenarios are shown on Table 3.

Table 3. Economic Analysis for the WF installation scenarios in Kythira Island

\begin{tabular}{|c|c|c|c|c|c|c|c|}
\hline SCENARIO No. & SCE_1 & SCE_2 & SCE_3 & SCE_4 & SCE_5 & SCE_6 & SCE_7 \\
\hline Cost per KW [M€] & 1950 & 1949.3 & 1948.9 & 1948.03 & 1947.03 & 1917.05 & 1850 \\
\hline Capacity [MW] & 122 & 112 & 102 & 92 & 82 & 51 & 21 \\
\hline GWh produced & 392.82 & 360.53 & 325.71 & 289.96 & 259.08 & 156.50 & 58.41 \\
\hline Net Operating Hours & 3219.30 & 3219.03 & 3193.26 & 3151.71 & 3159.56 & 3068.58 & 2781.62 \\
\hline Project Cost [M€] & 237.90 & 218.32 & 198.79 & 179.22 & 159.66 & 97.77 & 38.85 \\
\hline Subsidy & $32.81 \%$ & $33.01 \%$ & $33.39 \%$ & $33.88 \%$ & $34.46 \%$ & $37.29 \%$ & $33.10 \%$ \\
\hline Debt & $42.19 \%$ & $41.99 \%$ & $41.61 \%$ & $41.12 \%$ & $40.54 \%$ & $37.71 \%$ & $41.90 \%$ \\
\hline Equity & $25.00 \%$ & $25.00 \%$ & $25.00 \%$ & $25.00 \%$ & $25.00 \%$ & $25.00 \%$ & $25.00 \%$ \\
\hline Interest Rate & $7.00 \%$ & $7.00 \%$ & $7.00 \%$ & $7.00 \%$ & $7.00 \%$ & $7.00 \%$ & $7.00 \%$ \\
\hline NPV [M€] & 236.98 & 217.01 & 194.86 & 171.89 & 153.31 & 89.58 & 35.03 \\
\hline Project IRR & $21.60 \%$ & $21.61 \%$ & $21.29 \%$ & $20.76 \%$ & $20.96 \%$ & $20.46 \%$ & $18.25 \%$ \\
\hline Payback Period (yrs) & 6 & 6 & 6 & 6 & 6 & 6 & 7 \\
\hline
\end{tabular}

The proposed WF planning options for all the different examined scenarios (122 MW, $112 \mathrm{MW}, 102 \mathrm{MW}, 92 \mathrm{MW}, 82 \mathrm{MW}, 51 \mathrm{MW}$, and $21 \mathrm{MW})$ are shown in figure 7. 


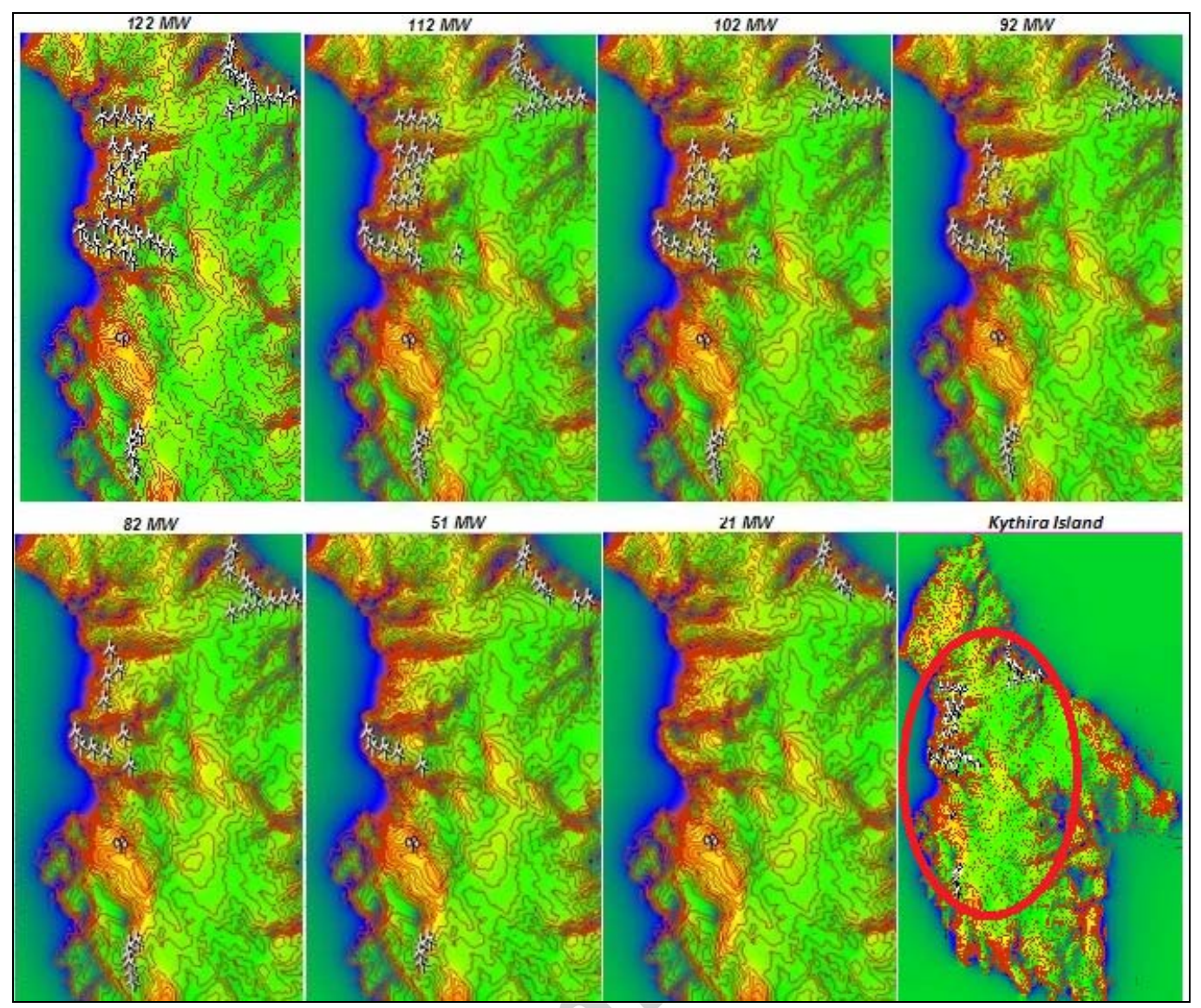

Figure 7. Proposed WF planning scenarios in Kythira Island

Several indices can compare economically different scenarios examined for the Wind Farm development strategy on the island and assist decision makers to optimize Wind Farm planning on the island. Figure 8, shows the relation between proposed WF capacity and project IRR, the ratio project IRR /(Subsidy \%), and the ratio NPV/Subsidy. 

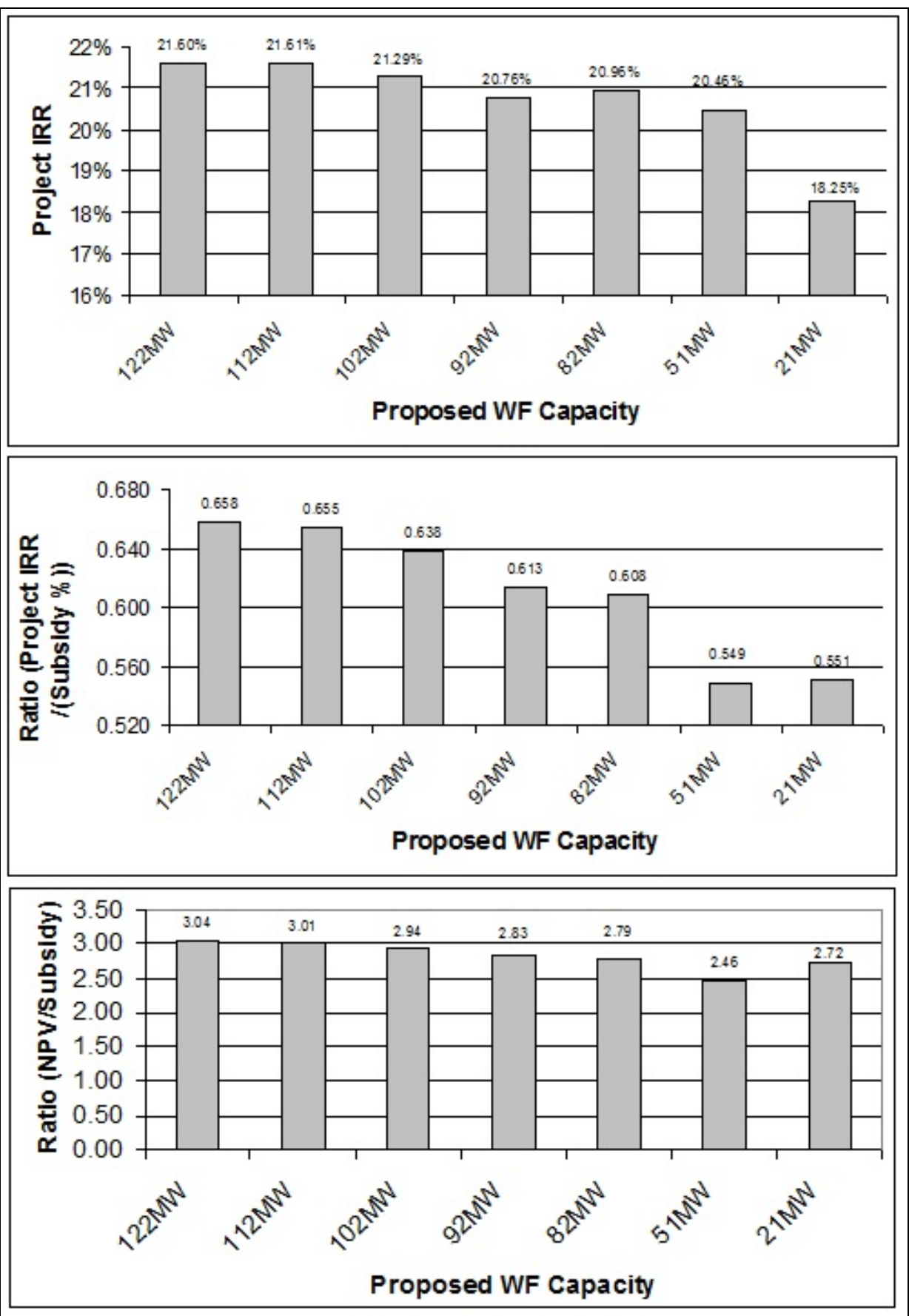

Figure 8. Indices assisting decision makers for the proposed WF project in Kythira Island

It is clear from the last two diagrams that the bigger the fraction the more profitable is the investment, however from the first diagram it is obvious that even with a very small difference the scenario of $112 \mathrm{MW}$ it has a higher project IRR. Project IRR or 
NPV were taken as a fraction numerator and subsidy or subsidy \% was taken as a denominator in the fraction as the idea was to get the fraction with the highest possible value. Introducing these indices it is easily understandable that the goal, in terms of improving social welfare, is to - at the same time - increase the profits for the investor, lowering as much as possible the state subsidization for the proposed projects.

\section{Conclusions}

In this paper a detailed wind resource analysis of Kythira Island was done and an spatial and an economic analysis was done in order to discover the optimum solution for the exploitation of the dominating wind energy in the island in order the isolated island to be HV interconnected with the mainland. The aim was to develop a case study in order to support an analyzing method focused, of course, in the optimal planning that is necessary however to be followed for all private investments which the state partly subsidizes. Aiming at decreasing the state subsidization and at the same time maximizing the investor profit, respecting all environmental constraints, the study showed that it is not possible the $322.15 \mathrm{MW}$ of proposed Wind Farms to be constructed in the island. Following the results of the spatial analysis it was found that only up to $122 \mathrm{MW}$ could be developed and proceed seriously to construction. Also, taking into consideration the results of the economic analysis it was found that either 122 or 112 MW could at the same time satisfy the need for increasing the profits of the investor and the need for low subsidization from the state (prerequisite due to the constant deepening of the Greek dept crisis). In practice, it is shown that for the last scenario, SCE_7 (table 3), the Project IRR is significantly lower than in the other 
cases $(18.25 \%)$ and partly out of the scope of this paper as it does not contribute to the HV interconnection plan of Kythira Island with the mainland (21 MW only need a medium voltage submarine cable). However, it was studied in order to offer to the reader a more holistic approach and the ability to compare. The indices (Project IRR / Subsidy \%) introduced shows quite clearly that either the scenario of 122 MW or 112 MW should be developed, as an alternative the plan of $102 \mathrm{MW}$ and only if this is not possible then to proceed to the 92 or $82 \mathrm{MW}$. It seems that the scenarios of 51 or 21 MW should be avoided. The other index introduced, NPV / Subsidy, deadens these gaps, however, it stresses once again the importance of the first two scenarios.

In any case, the need to optimize the planning and the use of the renewable energy, is becoming more intense, especially nowadays, day after day in an economically fickle world and more studies should follow towards that direction.

\section{Acknowledgements}

The preparation of this paper would not have been possible without the support and valuable contribution of the Certified Laboratory of Wind Measurements of Vector Hellenic Windfarms S.A.. The used data array was made up of the average (1 value per second - 600 values in $10 \mathrm{~min}$ ) and maximum 10-min wind speed values in the sites monitored by Vector - Hellenic Wind Farms S.A. 


\section{References}

[1] Mortensen NG, Landsberg L, Troen I, Petersen EL. Wind atlas analysis and application program (WAsP). Roskilde, Denmark: Risø Nat. Labs; 1993, 126pp.

[2] WindRose - A wind data analysis tool, User's Guide, Centre for Renewable Energy Sources, 2010, Available online: http://www.windrose.gr

[3] Hatziargyriou, N.D., Vrontisi, Z., Tsikalakis, A.G., Kilias, V., The effect of island interconnections on the increase of wind power penetration in the Greek system, 2007, 2007 IEEE Power Engineering Society General Meeting, PES , art. no. 4275747

[4] Georgiou, P.N., Mavrotas, G., Diakoulaki, D., The effect of islands' interconnection to the mainland system on the development of renewable energy sources in the Greek power sector, 2011, Renewable and Sustainable Energy Reviews 15 (6), pp. 2607-2620

[5] Papadopoulos M, Papathanassiou S., Interconnection of the Cyclades islands to the mainland system. Final report, Athens, National Technical University of Athens, School of Electrical and Computer Engineering, Division of Electric Power; 2005. Available from: http://www.rae.gr/cases/C11/index.html 
[6] Papadopoulos M, Papathanassiou S, Tsili M, Karamanou E. Interconnection strategy of islands to the mainland grid. Athens: National Technical University of Athens, School of Electrical and Computer Engineering, Division of Electric Power; 2006. Accessed from: http://www.rae.gr/cases/C19

[7] E. Karamanou, S. Papathanassiou and M. Papadopoulos, Planning the interconnection of islands to the mainland grid via submarine cables, Med power $2008-6^{\text {th }}$ mediterranean conference and exhibition on power generation, transmission, distribution and energy conversion Thessaloniki, 2008

[8] Hellenic Transmission System Operator (HTSO), Interconnection Study for the Aegean islands and the Mainland - Phase A', 2009, Available from: http://www.desmie.gr

[9] Development Study of the electrical system of the island of Crete. Interconnection with the Mainland, Regulatory Authority for Energy - Hellenic Transmission System Operator - Public Power Coorporation, April 2011, Available from: http://www.ypeka.gr/LinkClick.aspx?fileticket=vFPxYoCvpwo\%3D\&tabid=367\&lan guage $=\mathrm{el}-\mathrm{GR}$

[10] Palaiologou, P., Kalabokidis, K., Haralambopoulos, D., Feidas, H., Polatidis, H., Wind characteristics and mapping for power production in the Island of Lesvos, Greece, 2011, Computers and Geosciences, Article in Press 
[11] Prasad, R.D., Bansal, R.C., Sauturaga, M., Wind energy analysis for vadravadra site in Fiji Islands: A case study, 2009, IEEE Transactions on Energy Conversion 24 (3), pp. 750-757

[12] Segurado, R., Krajačić, G., Duić, N., Alves, L., Increasing the penetration of renewable energy resources in S. Vicente, Cape Verde, 2011, Applied Energy 88 (2), pp. $466-472$

[13] Liu, H.-Y., Wu, S.-D., An assessment on the planning and construction of an island renewable energy system - A case study of Kinmen Island, 2010, Renewable Energy 35 (12), pp. 2723-2731

[14] Kaldellis, J.K., Kapsali, M., Kavadias, K.A., Energy balance analysis of windbased pumped hydro storage systems in remote island electrical networks, 2010, Applied Energy 87 (8), pp. 2427-2437

[15] Kumar Nandi, S., Ranjan Ghosh, H., Techno-economical analysis of off-grid hybrid systems at Kutubdia Island, Bangladesh, 2010, Energy Policy 38 (2), pp. 976980

[16] Giatrakos, G.P., Tsoutsos, T.D., Mouchtaropoulos, P.G., Naxakis, G.D., Stavrakakis, G., Sustainable energy planning based on a stand-alone hybrid renewableenergy/hydrogen power system: Application in Karpathos island, Greece, 2009, Renewable Energy 34 (12), pp. 2562-2570 
[17] Darus, Z.M., Hashim, N.A., Manan, S.N.A., Rahman, M.A.A., Maulud, K.N.A., Karim, O.A., The development of hybrid integrated renewable energy system (wind and solar) for sustainable living at Perhentian Island, Malaysia, 2009, European Journal of Social Sciences 11 (2), pp. 198-204

[18] Dua, M., Manwell, J.F., McGowan, J.G., Utility scale wind turbines on a gridconnected island: A feasibility study, 2008, Renewable Energy 33 (4), pp. 712-719

[19] Celik AN., A statistical analysis of wind power density based on the Weibull and Rayleigh models at the southern region of Turkey. Renewable Energy, 2003; 29, pp. 593-604, DOI: 10.1016/j.renene.2003.07.002

[20] Garcia A, Torres JL, Prieto E, De Francisco A. Fitting probability density distributions: a case study. Solar Energy 1998; 62(2), pp. 139-144.

[21] Jamil M, Parsa S, Majidi M. Wind power statistics and an evaluation of wind energy density. Renewable Energy 1995; 6, pp. 623-628

[22] Vogiatzis N, Kotti K, Spanomitsios S, Stoukides M. Analysis of wind potential and characteristics in North Aegean, Greece. Renewable Energy 2004; 29, pp. $1193-$ 1208, DOI: 10.1016/j.renene.2003.11.017

[23] Kose R, Ozgur MA, Erbas O, Tugcu A. The analysis of wind data and energy potential in Kutahya, Turkey. Renewable and Sustainable Energy Reviews 2004; 8, pp. 277-288, DOI: 10.1016/j.rser.2003.11.003 
[24] Rehman S. Wind energy resources assessment for Yanbo, Saudi Arabia. Energy Conversion and Management 2004; 45, pp 2019-2032, DOI: 10.1016/j.enconman.2003.11.009

[25] Kaldellis JK. Wind energy management. Athens: Stamoulis Publications; 1999

[26] Applications for power production licensing, Archive, Regulatory Authority for Energy, 2011, Available from (in Greek only): http://www.rae.gr/site/system/docs/registry/ape_sithia.csp?viewMode=normal

[27] Law 3908, Aid for Private Investment to promote Economic Growth, Entrepreneurship and Regional Cohesion, 2010, Available from: http://www.ependyseis.gr/sub/nomos3908/files/N3908_en_official_translation.pdf

[28] Butler, L., Neuhoff, K., Comparison of feed-in tariff, quota and auction mechanisms to support wind power development. Renewable Energy, 2008 33, pp. $1854-1867$.

[29] Gonzalez, P., Ten years of renewable electricity policies in Spain: Analysis of successive feed-in tariff reforms, Energy Policy, 2008, 36, pp. 2917-2929.

[30] J.K. Kaldellis, Critical evaluation of financial supporting schemes for wind-based projects - Case study Greece, Energy Policy, 39 (2011), pp. 2490-2500 
[31] Hepbasli, A., Alsuhaibani, Z., Exergetic and exergoeconomic aspects of wind energy systems in achieving sustainable development, 2011, Renewable and Sustainable Energy Reviews 15 (6), pp. 2810-2825

[32] G. Xydis, Effects of air psychrometrics on the exergetic efficiency of a wind farm at a coastal mountainous site - An experimental study, 2012, Energy 37 (1), pp. $632-638$

[33] Special Framework for Spatial Planning of Renewable Energy, Ministry of Environment, Energy and Climate Change, 2008, Available from: http://www.minenv.gr/4/42/00/KYA.APE.January.2008.pdf

[34] Law 3851/2010, “Accelerating the development of Renewable Energy Sources to deal with climate change and other regulations addressing issues under the authority of the Ministry of Environment, Energy and Climate Change", Ministry of Environment, Energy and Climate Change, 2010, Available from: http://www.ypeka.gr/LinkClick.aspx?fileticket=qtiW90JJLYs\%3D\&tabid=37

[35] Wind Energy Resource Atlas of the United States, 2010, Available from: http://rredc.nrel.gov/wind/pubs/atlas/

[36] Consent of the Interconnection to the Transmission System, RAE study, 2007, Available from: http://www.rae.gr/old/cases/C9/rae-2-2007.pdf 
[37] Klaus-Ole Vogstad. Energy resource planning; integrating wind power, Diploma thesis, SMU/pav. B/NTNU/7034 Trondheim/Norway

[38] Hellenic Transmission System Operator. Interconnection Offer, 2009

[39] Vector Hellenic Wind Farms S.A., Available from: http://www.windfarms.gr/en/home.html, personal contact

[40] Rokas Renewables - An Iberdrola Renewables company, Available from: http://www.rokasgroup.gr/en/index.html, personal contact

[41] The economics of wind energy, RenewableUK, Available from: http://www.bwea.com/ref/econ.html 


\section{Appendix}

Table A1. Detailed Results of the 122 MW scenario

\begin{tabular}{|c|c|c|c|c|c|c|c|c|c|c|c|}
\hline $\begin{array}{l}\text { WF1 } \\
(18 \mathrm{MW})\end{array}$ & Site & $\begin{array}{l}\text { Elev. } \\
{[\mathrm{m}]}\end{array}$ & $\begin{array}{l}\mathrm{HH} \\
{[\mathrm{m}]}\end{array}$ & $\begin{array}{c}\mathrm{U} \\
{[\mathrm{m} / \mathrm{s}]}\end{array}$ & $\begin{array}{l}\text { Gross } \\
{[\mathrm{GWh}]}\end{array}$ & $\begin{array}{c}\text { Net } \\
\text { (incl. } \\
\text { topo) } \\
\text { [GWh] }\end{array}$ & $\begin{array}{c}\text { Topo } \\
\text { Losses } \\
\text { [\%] }\end{array}$ & $\begin{array}{c}\text { Air } \\
\text { Dens. } \\
\text { Losses } \\
{[\%]}\end{array}$ & $\begin{array}{c}\text { Interconnection } \\
\text { Losses [\%] }\end{array}$ & $\begin{array}{c}\text { WT technical } \\
\text { availability } \\
\text { losses [\%] }\end{array}$ & $\begin{array}{c}\text { Net } \\
{[\mathrm{GWh}]}\end{array}$ \\
\hline \multirow{7}{*}{ 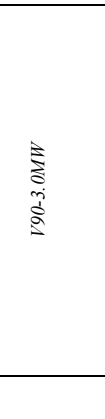 } & WT1 & 260 & 78 & 8.93 & 11.44 & 11.17 & 2.36 & \multirow{7}{*}{3.40} & \multirow{7}{*}{2.15} & \multirow{7}{*}{3.00} & \multirow{7}{*}{57.45} \\
\hline & WT2 & 221 & 78 & 8.54 & 10.759 & 10.487 & 2.53 & & & & \\
\hline & WT3 & 205 & 78 & 9.15 & 12.02 & 11.778 & 2.01 & & & & \\
\hline & WT4 & 144 & 78 & 8.46 & 10.669 & 10.503 & 1.56 & & & & \\
\hline & WT5 & 224 & 78 & 7.79 & 9.28 & 9.048 & 2.49 & & & & \\
\hline & WT6 & 221 & 78 & 8.21 & 10.056 & 9.952 & 1.03 & & & & \\
\hline & TOT & & 291 & 8.51 & 64.224 & & 2.00 & & & & \\
\hline $\begin{array}{c}\text { WF2 } \\
(18 \mathrm{MW})\end{array}$ & Site & $\begin{array}{l}\text { Elev. } \\
{[\mathrm{m}]}\end{array}$ & $\begin{array}{l}\mathrm{Ht} \\
{[\mathrm{m}]}\end{array}$ & $\begin{array}{c}\mathrm{U} \\
{[\mathrm{m} / \mathrm{s}]}\end{array}$ & $\begin{array}{l}\text { Gross } \\
{[\mathrm{GWh}]}\end{array}$ & $\begin{array}{l}\text { Net } \\
\text { (incl. } \\
\text { topo) } \\
\text { [GWh] }\end{array}$ & $\begin{array}{c}\text { Topo } \\
\text { Losses } \\
{[\%]}\end{array}$ & $\begin{array}{l}\text { Dens. } \\
\text { Losses } \\
{[\%]}\end{array}$ & $\begin{array}{c}\text { Interconnection } \\
\text { Losses [\%] }\end{array}$ & $\begin{array}{c}\text { WT technical } \\
\text { availability } \\
\text { losses [\%] }\end{array}$ & $\begin{array}{c}\text { Net } \\
{[\mathrm{GWh}]}\end{array}$ \\
\hline \multirow{7}{*}{ 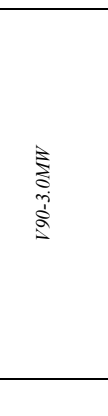 } & WT1 & 361 & 78 & 9.18 & 11.843 & 11.603 & 2.03 & \multirow{7}{*}{4.24} & \multirow{7}{*}{6.05} & \multirow{7}{*}{3.00} & \multirow{7}{*}{54.44} \\
\hline & WT2 & 261 & 78 & 7.9 & 9.519 & 9.443 & 0.8 & & & & \\
\hline & WT3 & 323 & 78 & 9.03 & 11.508 & 11.41 & 0.85 & & & & \\
\hline & WT4 & 259 & 78 & 8.04 & 9.756 & 9.619 & 1.41 & & & & \\
\hline & WT5 & 278 & 78 & 8.35 & 10.35 & 10.253 & 0.94 & & & & \\
\hline & WT6 & 282 & 78 & 8.55 & 10.722 & 10.575 & 1.37 & & & & \\
\hline & TOT & & $\underline{372}$ & 8.51 & 63.698 & & 1.23 & & & & \\
\hline $\begin{array}{c}\text { WF3 } \\
(18 \mathrm{MW})\end{array}$ & Site & $\begin{array}{l}\text { Elev. } \\
{[\mathrm{m}]}\end{array}$ & $\begin{array}{l}\mathrm{Ht} \\
{[\mathrm{m}]}\end{array}$ & $\begin{array}{c}\mathrm{U} \\
{[\mathrm{m} / \mathrm{s}]}\end{array}$ & $\begin{array}{l}\text { Gross } \\
{[\mathrm{GWh}]}\end{array}$ & $\begin{array}{c}\text { Net } \\
\text { (incl. } \\
\text { topo) } \\
{[\mathrm{GWh}]}\end{array}$ & $\begin{array}{c}\text { Topo } \\
\text { Losses } \\
{[\%]}\end{array}$ & $\begin{array}{c}\text { Air } \\
\text { Dens. } \\
\text { Losses } \\
{[\%]}\end{array}$ & $\begin{array}{c}\text { Interconnection } \\
\text { Losses [\%] }\end{array}$ & $\begin{array}{c}\text { WT technical } \\
\text { availability } \\
\text { losses [\%] }\end{array}$ & $\begin{array}{c}\text { Net } \\
{[\mathrm{GWh}]}\end{array}$ \\
\hline \multirow{7}{*}{ 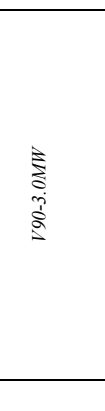 } & WT1 & 201 & 78 & 8.38 & 10.492 & 10.318 & 1.65 & \multirow{7}{*}{3.92} & \multirow{7}{*}{3.88} & \multirow{7}{*}{3.00} & \multirow{7}{*}{51.90} \\
\hline & WT2 & 300 & 78 & 7.97 & 9.645 & 9.544 & 1.04 & & & & \\
\hline & WT3 & 294 & 78 & 8.16 & 10.028 & 9.779 & 2.48 & & & & \\
\hline & WT4 & 269 & 78 & 8.03 & 9.761 & 9.464 & 3.04 & & & & \\
\hline & WT5 & 248 & 78 & 8.03 & 9.752 & 9.434 & 3.26 & & & & \\
\hline & WT6 & 230 & 78 & 8.19 & 10.09 & 9.815 & 2.73 & & & & \\
\hline & TOT & & 335 & 8.13 & 59.768 & & 2.37 & & & & \\
\hline
\end{tabular}




\begin{tabular}{|c|c|c|c|c|c|c|c|c|c|c|c|}
\hline $\begin{array}{c}\text { WF4 } \\
(24 \mathrm{MW})\end{array}$ & Site & $\begin{array}{l}\text { Elev. } \\
{[\mathrm{m}]}\end{array}$ & $\begin{array}{l}\mathrm{Ht} \\
{[\mathrm{m}]}\end{array}$ & $\begin{array}{c}\mathrm{U} \\
{[\mathrm{m} / \mathrm{s}]}\end{array}$ & $\begin{array}{l}\text { Gross } \\
{[\mathrm{GWh}]}\end{array}$ & $\begin{array}{l}\text { Net } \\
\text { (incl. } \\
\text { topo) } \\
\text { [GWh] }\end{array}$ & $\begin{array}{c}\text { Topo } \\
\text { Losses } \\
{[\%]}\end{array}$ & $\begin{array}{c}\text { Air } \\
\text { Dens. } \\
\text { Losses } \\
{[\%]}\end{array}$ & $\begin{array}{c}\text { Interconnection } \\
\text { Losses [\%] }\end{array}$ & $\begin{array}{l}\text { WT technical } \\
\text { availability } \\
\text { losses [\%] }\end{array}$ & $\begin{array}{c}\text { Net } \\
{[\mathrm{GWh}]}\end{array}$ \\
\hline \multirow{9}{*}{ 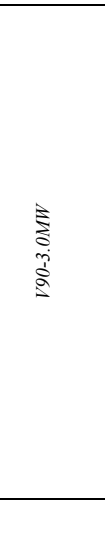 } & WT1 & 264 & 78 & 8.23 & 10.181 & 9.992 & 1.86 & \multirow{9}{*}{3.50} & \multirow{9}{*}{3.45} & \multirow{9}{*}{3.00} & \multirow{9}{*}{72.42} \\
\hline & WT2 & 240 & 78 & 8.68 & 10.981 & 10.739 & 2.21 & & & & \\
\hline & WT3 & 261 & 78 & 8.46 & 10.651 & 10.092 & 5.25 & & & & \\
\hline & WT4 & 239 & 78 & 7.79 & 9.262 & 8.694 & 6.13 & & & & \\
\hline & WT5 & 229 & 78 & 9.28 & 11.984 & 11.826 & 1.32 & & & & \\
\hline & WT6 & 156 & 78 & 8.52 & 10.626 & 10.51 & 1.1 & & & & \\
\hline & WT7 & 233 & 78 & 8.03 & 9.764 & 9.384 & 3.89 & & & & \\
\hline & WT8 & 266 & 78 & 8.33 & 10.382 & 9.939 & 4.26 & & & & \\
\hline & TOT & & $\underline{309}$ & 8.40 & 83.831 & & 3.66 & & & & \\
\hline $\begin{array}{c}\text { WF5 } \\
\text { (44MW) }\end{array}$ & Site & $\begin{array}{l}\text { Elev. } \\
{[\mathrm{m}]}\end{array}$ & $\begin{array}{l}\mathrm{Ht} \\
{[\mathrm{m}]}\end{array}$ & $\begin{array}{c}\mathrm{U} \\
{[\mathrm{m} / \mathrm{s}]}\end{array}$ & $\begin{array}{l}\text { Gross } \\
{[\mathrm{GWh}]}\end{array}$ & $\begin{array}{c}\text { Net } \\
\text { (incl. } \\
\text { topo) } \\
\text { [GWh] }\end{array}$ & $\begin{array}{c}\text { Topo } \\
\text { Losses } \\
{[\%]}\end{array}$ & $\begin{array}{c}\text { Air } \\
\text { Dens. } \\
\text { Losses }\end{array}$ & $\begin{array}{l}\text { Interconnection } \\
\text { Losses [\%] }\end{array}$ & $\begin{array}{c}\text { WT technical } \\
\text { availability } \\
\text { losses [\%] }\end{array}$ & $\begin{array}{c}\text { Net } \\
{[\mathrm{GWh}]}\end{array}$ \\
\hline \multirow{20}{*}{ 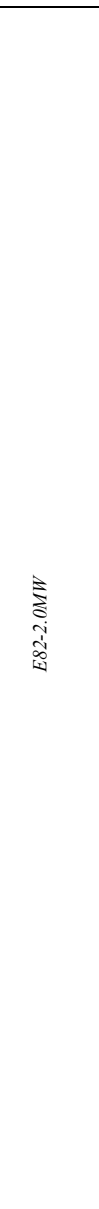 } & WT1 & 196 & 78 & 8.3 & 8.318 & 7.976 & 4.11 & \multirow{20}{*}{4.50} & \multirow{20}{*}{6.59} & \multirow{20}{*}{3.00} & \multirow{20}{*}{156.60} \\
\hline & WT2 & 166 & 78 & 7.53 & 7.238 & 6.979 & 3.59 & & & & \\
\hline & WT3 & 240 & 78 & 9.1 & 9.153 & 8.834 & 3.49 & & & & \\
\hline & WT4 & 261 & 78 & 9.22 & 9.346 & 9.116 & 2.46 & & & & \\
\hline & WT5 & 262 & 78 & 9.22 & 9.534 & 9.192 & 3.59 & & & & \\
\hline & WT6 & 240 & 78 & 8.47 & 8.547 & 8.09 & 5.35 & & & & \\
\hline & WT7 & 266 & 78 & 8.94 & 9.156 & 8.753 & 4.4 & & & & \\
\hline & WT8 & 260 & 78 & 8.75 & 8.824 & 8.391 & 4.91 & & & & \\
\hline & WT9 & 300 & 78 & 9.19 & 9.328 & 8.955 & 4 & & & & \\
\hline & WT10 & 281 & 78 & 8.75 & 8.808 & 8.333 & 5.39 & & & & \\
\hline & WT11 & 300 & 78 & 8.91 & 9.171 & 8.795 & 4.09 & & & & \\
\hline & WT12 & 283 & 78 & 8.55 & 8.666 & 8.193 & 5.46 & & & & \\
\hline & WT13 & 294 & 78 & 8.7 & 8.773 & 8.495 & 3.16 & & & & \\
\hline & WT14 & 280 & 78 & 8.92 & 9.042 & 8.691 & 3.89 & & & & \\
\hline & WT15 & 301 & 78 & 8.58 & 8.635 & 8.27 & 4.23 & & & & \\
\hline & WT16 & 271 & 78 & 7.78 & 7.641 & 7.278 & 4.75 & & & & \\
\hline & WT17 & 303 & 78 & 8.58 & 8.696 & 8.232 & 5.35 & & & & \\
\hline & WT18 & 320 & 78 & 8.74 & 8.826 & 8.481 & 3.91 & & & & \\
\hline & WT19 & 292 & 78 & 8.03 & 8.005 & 7.592 & 5.16 & & & & \\
\hline & WT20 & 328 & 78 & 8.6 & 8.747 & 8.443 & 3.48 & & & & \\
\hline
\end{tabular}




\begin{tabular}{|c|c|c|c|c|c|c|c|c|}
\hline WT21 & 316 & 78 & 8.17 & 8.197 & 7.87 & 3.99 & & \\
\hline WT22 & 341 & 78 & 8.4 & 8.457 & 8.296 & 1.91 & & \\
\hline TOT & & $\underline{395}$ & 8.42 & 191.108 & & 3.97 & & \\
\hline & & - & & & & & 4* & \\
\hline $\begin{array}{l}\text { OVERALL } \\
\text { TOTAL }\end{array}$ & & 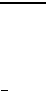 & & & & & & 392.82 \\
\hline
\end{tabular}

Table A2. RAE's estimation on the costs of High Voltage transmission Lines

\begin{tabular}{|c|c|}
\hline Type of High Voltage Line & Estimated Cost $(\mathrm{k} € / \mathbf{k m})$ \\
\hline $\mathrm{E} / 150 \mathrm{kV}$ (length at least $10 \mathrm{~km}$ ) & 75 \\
\hline $\mathrm{E} / 150 \mathrm{kV}$ (length at least $1.5 \mathrm{~km}$ ) & 110 \\
\hline $\mathrm{B} / 150 \mathrm{kV}$ (length at least $10 \mathrm{~km}$ ) & 100 \\
\hline $\mathrm{B} / 150 \mathrm{kV}$ (length at least $1.5 \mathrm{~km}$ ) & 145 \\
\hline 2B/150 kV (length at least $10 \mathrm{~km}$ ) & 135 \\
\hline $2 \mathrm{~B} / 150 \mathrm{kV}$ (length at least $1.5 \mathrm{~km}$ ) & 195 \\
\hline $\mathrm{B}^{\prime} \mathrm{B}^{\prime} / 400 \mathrm{kV}$ (length at least $\left.10 \mathrm{~km}\right)$ & 195 \\
\hline $\mathrm{B}^{\prime} \mathrm{B}^{\prime} / 400 \mathrm{kV}$ (length at least $1.5 \mathrm{~km}$ ) & 270 \\
\hline 2B'B'/400 kV (length at least $10 \mathrm{~km}$ ) & 315 \\
\hline 2B'B'/400 kV (length at least $1.5 \mathrm{~km}$ ) & 460 \\
\hline B'B'B'/400 kV (length at least $10 \mathrm{~km}$ ) & 240 \\
\hline B'B'B'/400 kV (length at least $1.5 \mathrm{~km}$ ) & 340 \\
\hline $150 \mathrm{kV}$ (underground - single cable) & 500 \\
\hline $150 \mathrm{kV}$ (underground - double cable) & 850 \\
\hline $150 \mathrm{kV}$ (submarine cable: $3+1$ backup cable) & per case \\
\hline
\end{tabular}

Table 1. Main measured characteristics of the wind mast 


\begin{tabular}{|c|c|c|c|c|c|}
\hline $\begin{array}{c}\text { Latitude } \\
\left(^{\circ}\right)\end{array}$ & $\begin{array}{c}\text { Longitude } \\
\left({ }^{\circ}\right)\end{array}$ & $\begin{array}{c}\text { Mean speed } \\
\left(\mathrm{m} \cdot \mathrm{s}^{-1}\right)\end{array}$ & $\begin{array}{l}\text { Period of } \\
\text { data } \\
\text { analysis }\end{array}$ & $\begin{array}{l}\text { Height } \\
\text { (magl) }\end{array}$ & $\begin{array}{l}\text { Av. Turbulence } \\
\text { Intensity } \\
\text { (at } 10 \mathrm{~m} . \text { ) }\end{array}$ \\
\hline $36^{\circ} 13^{\prime} 45.67^{\prime \prime} \mathrm{N}$ & $22^{\circ} 56^{\prime} 27.33^{\prime \prime} \mathrm{E}$ & $\begin{array}{l}8.22 \text { at } \\
20 \mathrm{~m} .\end{array}$ & $\begin{array}{l}22 \text { Oct '07- } \\
22 \text { Oct ' } 08\end{array}$ & 470 & $11.137 \%$ \\
\hline
\end{tabular}

Table 2. Weibull distribution analysis of Kythira Island mast

\begin{tabular}{|c|c|c|c|c|c|c|}
\hline Direction & Angles (deg) & $\begin{array}{l}\text { Weibull } \\
\text { shape }\end{array}$ & $\begin{array}{c}\text { Weibull } \\
\text { scale }\end{array}$ & $\begin{array}{c}\text { Data } \\
\text { Distrib }\end{array}$ & $\begin{array}{l}\text { Mean Wind } \\
\text { Speed }(\mathrm{m} / \mathrm{s})\end{array}$ & $\begin{array}{l}\text { T.I. at } \\
10 \mathrm{~m} / \mathrm{s}\end{array}$ \\
\hline NNE & $11.25-33.75$ & 1.78 & 7.18 & $0.55 \%$ & 6.5 & 9.3 \\
\hline NE & $33.75-56.25$ & 1.61 & 6.76 & $1.14 \%$ & 6.2 & 9.3 \\
\hline ENE & $56.25-78.75$ & 2.21 & 7.37 & $2.92 \%$ & 6.6 & 9.4 \\
\hline $\mathbf{E}$ & $78.75-101.25$ & 1.86 & 10.83 & $11.86 \%$ & 9.4 & 10.2 \\
\hline ESE & $101.25-123.75$ & 1.94 & 12.99 & $12.94 \%$ & 11.4 & 10.0 \\
\hline SE & $123.75-146.25$ & 2.34 & 12.49 & $12.18 \%$ & 11.1 & 10.4 \\
\hline SSE & $146.25-168.75$ & 1.54 & 6.11 & $3.66 \%$ & 5.7 & 9.1 \\
\hline $\mathbf{S}$ & $168.75-191.25$ & 1.47 & 4.29 & $3.38 \%$ & 4.3 & 11.3 \\
\hline SSW & $191.25-213.75$ & 1.51 & 5.44 & $4.03 \%$ & 5.1 & 14.3 \\
\hline SW & $213.75-236.25$ & 1.99 & 6.66 & $7.18 \%$ & 5.9 & 19.4 \\
\hline WSW & $236.25-258.75$ & 1.91 & 8.26 & $12.23 \%$ & 7.4 & 13.8 \\
\hline $\mathbf{W}$ & $258.75-281.25$ & 1.73 & 8.07 & $10.14 \%$ & 7.3 & 10.8 \\
\hline WNW & $281.25-303.75$ & 1.37 & 7.78 & $7.45 \%$ & 7.2 & 8.8 \\
\hline NW & $303.75-326.25$ & 1.51 & 7.63 & $5.44 \%$ & 7.0 & 9.2 \\
\hline NNW & $326.25-348.75$ & 1.97 & 10.36 & $4.46 \%$ & 9.1 & 9.2 \\
\hline $\mathbf{N}$ & $348.75-11.25$ & 1.43 & 5.46 & $0.44 \%$ & 4.4 & 10.0 \\
\hline
\end{tabular}

Table 3. Economic Analysis for the WF installation scenarios in Kythira Island 


\begin{tabular}{|c|c|c|c|c|c|c|c|}
\hline SCENARIO No. & SCE_1 & SCE_2 & SCE_3 & SCE_4 & SCE_5 & SCE_6 & SCE_7 \\
\hline Cost per KW [M€] & 1950 & 1949.3 & 1948.9 & 1948.03 & 1947.03 & 1917.05 & 1850 \\
\hline Capacity [MW] & 122 & 112 & 102 & 92 & 82 & 51 & 21 \\
\hline GWh produced & 392.82 & 360.53 & 325.71 & 289.96 & 259.08 & 156.50 & 58.41 \\
\hline Net Operating Hours & 3219.30 & 3219.03 & 3193.26 & 3151.71 & 3159.56 & 3068.58 & 2781.62 \\
\hline Project Cost [M€] & 237.90 & 218.32 & 198.79 & 179.22 & 159.66 & 97.77 & 38.85 \\
\hline Subsidy & $32.81 \%$ & $33.01 \%$ & $33.39 \%$ & $33.88 \%$ & $34.46 \%$ & $37.29 \%$ & $33.10 \%$ \\
\hline Debt & $42.19 \%$ & $41.99 \%$ & $41.61 \%$ & $41.12 \%$ & $40.54 \%$ & $37.71 \%$ & $41.90 \%$ \\
\hline Equity & $25.00 \%$ & $25.00 \%$ & $25.00 \%$ & $25.00 \%$ & $25.00 \%$ & $25.00 \%$ & $25.00 \%$ \\
\hline Interest Rate & $7.00 \%$ & $7.00 \%$ & $7.00 \%$ & $7.00 \%$ & $7.00 \%$ & $7.00 \%$ & $7.00 \%$ \\
\hline NPV [M€] & 236.98 & 217.01 & 194.86 & 171.89 & 153.31 & 89.58 & 35.03 \\
\hline Project IRR & $21.60 \%$ & $21.61 \%$ & $21.29 \%$ & $20.76 \%$ & $20.96 \%$ & $20.46 \%$ & $18.25 \%$ \\
\hline Payback Period (yrs) & 6 & 6 & 6 & 6 & 6 & 6 & 7 \\
\hline
\end{tabular}

Table A1. Detailed Results of the 122 MW scenario

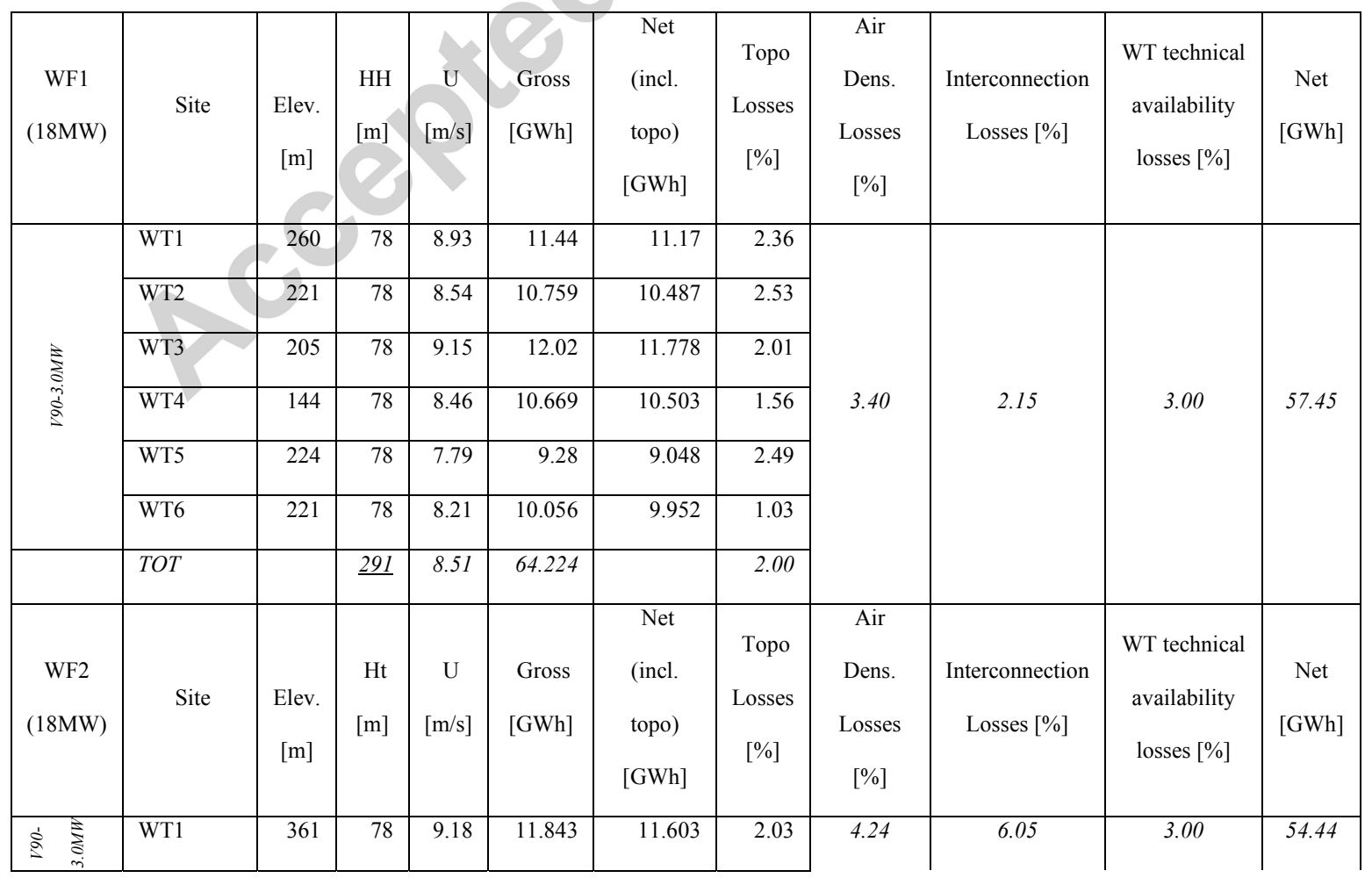




\begin{tabular}{|c|c|c|c|c|c|c|c|c|c|c|c|}
\hline & WT2 & 261 & 78 & 7.9 & 9.519 & 9.443 & 0.8 & & & & \\
\hline & WT3 & 323 & 78 & 9.03 & 11.508 & 11.41 & 0.85 & & & & \\
\hline & WT4 & 259 & 78 & 8.04 & 9.756 & 9.619 & 1.41 & & & & \\
\hline & WT5 & 278 & 78 & 8.35 & 10.35 & 10.253 & 0.94 & & & & \\
\hline & WT6 & 282 & 78 & 8.55 & 10.722 & 10.575 & 1.37 & & & & \\
\hline & $T O T$ & & $\underline{372}$ & 8.51 & 63.698 & & 1.23 & & & & \\
\hline $\begin{array}{c}\text { WF3 } \\
\text { (18MW) }\end{array}$ & Site & $\begin{array}{l}\text { Elev. } \\
{[\mathrm{m}]}\end{array}$ & $\begin{array}{l}\mathrm{Ht} \\
{[\mathrm{m}]}\end{array}$ & $\begin{array}{c}\mathrm{U} \\
{[\mathrm{m} / \mathrm{s}]}\end{array}$ & $\begin{array}{l}\text { Gross } \\
\text { [GWh] }\end{array}$ & $\begin{array}{l}\text { Net } \\
\text { (incl. } \\
\text { topo) } \\
\text { [GWh] }\end{array}$ & $\begin{array}{c}\text { Topo } \\
\text { Losses } \\
{[\%]}\end{array}$ & $\begin{array}{c}\text { Air } \\
\text { Dens. } \\
\text { Losses } \\
{[\%]}\end{array}$ & $\begin{array}{l}\text { Interconnection } \\
\text { Losses [\%] }\end{array}$ & $\begin{array}{l}\text { WT technical } \\
\text { availability } \\
\text { losses [\%] }\end{array}$ & $\begin{array}{c}\text { Net } \\
{[\mathrm{GWh}]}\end{array}$ \\
\hline & WT1 & 201 & 78 & 8.38 & 10.492 & 10.318 & 1.65 & & & & \\
\hline & WT2 & 300 & 78 & 7.97 & 9.645 & 9.544 & 1.04 & & & & \\
\hline ह & WT3 & 294 & 78 & 8.16 & 10.028 & 9.779 & 2.48 & & & & \\
\hline కุ & WT4 & 269 & 78 & 8.03 & 9.761 & 9.464 & 3.04 & 3.92 & 3.88 & 3.00 & 51.90 \\
\hline & WT5 & 248 & 78 & 8.03 & 9.752 & 9.434 & 3.26 & & & & \\
\hline & WT6 & 230 & 78 & 8.19 & 10.09 & 9.815 & 2.73 & & & & \\
\hline & TOT & & $\underline{335}$ & 8.13 & 59.768 & & 2.37 & & & & \\
\hline $\begin{array}{c}\text { WF4 } \\
\text { (24MW) }\end{array}$ & Site & $\begin{array}{l}\text { Elev. } \\
{[\mathrm{m}]}\end{array}$ & $\begin{array}{l}\mathrm{Ht} \\
{[\mathrm{m}]}\end{array}$ & $\begin{array}{c}\mathrm{U} \\
{[\mathrm{m} / \mathrm{s}]}\end{array}$ & $\begin{array}{c}\text { Gross } \\
\text { [GWh] }\end{array}$ & $\begin{array}{l}\text { Net } \\
\text { (incl. } \\
\text { topo) } \\
\text { [GWh] }\end{array}$ & $\begin{array}{c}\text { Topo } \\
\text { Losses } \\
{[\%]}\end{array}$ & $\begin{array}{c}\text { Air } \\
\text { Dens. } \\
\text { Losses }\end{array}$ & $\begin{array}{l}\text { Interconnection } \\
\text { Losses [\%] }\end{array}$ & $\begin{array}{l}\text { WT technical } \\
\text { availability } \\
\text { losses [\%] }\end{array}$ & $\begin{array}{c}\text { Net } \\
{[G W h]}\end{array}$ \\
\hline \multirow{9}{*}{ 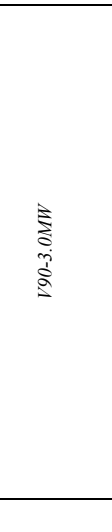 } & WT1 & 264 & 78 & 8.23 & 10.181 & 9.992 & 1.86 & \multirow{9}{*}{3.50} & \multirow{9}{*}{3.45} & \multirow{9}{*}{3.00} & \multirow{9}{*}{72.42} \\
\hline & WT2 & 240 & 78 & 8.68 & 10.981 & 10.739 & 2.21 & & & & \\
\hline & WT3 & 261 & 78 & 8.46 & 10.651 & 10.092 & 5.25 & & & & \\
\hline & WT4 & 239 & 78 & 7.79 & 9.262 & 8.694 & 6.13 & & & & \\
\hline & WT5 & 229 & 78 & 9.28 & 11.984 & 11.826 & 1.32 & & & & \\
\hline & WT6 & 156 & 78 & 8.52 & 10.626 & 10.51 & 1.1 & & & & \\
\hline & WT7 & 233 & 78 & 8.03 & 9.764 & 9.384 & 3.89 & & & & \\
\hline & WT8 & 266 & 78 & 8.33 & 10.382 & 9.939 & 4.26 & & & & \\
\hline & TOT & & $\underline{309}$ & 8.40 & 83.831 & & 3.66 & & & & \\
\hline $\begin{array}{c}\text { WF5 } \\
\text { (44MW) }\end{array}$ & Site & $\begin{array}{l}\text { Elev. } \\
{[\mathrm{m}]}\end{array}$ & $\begin{array}{l}\mathrm{Ht} \\
{[\mathrm{m}]}\end{array}$ & $\begin{array}{c}\mathrm{U} \\
{[\mathrm{m} / \mathrm{s}]}\end{array}$ & $\begin{array}{l}\text { Gross } \\
\text { [GWh] }\end{array}$ & $\begin{array}{l}\text { Net } \\
\text { (incl. } \\
\text { topo) } \\
\text { [GWh] }\end{array}$ & $\begin{array}{c}\text { Topo } \\
\text { Losses } \\
\text { [\%] }\end{array}$ & $\begin{array}{c}\text { Air } \\
\text { Dens. } \\
\text { Losses } \\
{[\%]}\end{array}$ & $\begin{array}{c}\text { Interconnection } \\
\text { Losses [\%] }\end{array}$ & $\begin{array}{l}\text { WT technical } \\
\text { availability } \\
\text { losses [\%] }\end{array}$ & $\begin{array}{c}\text { Net } \\
{[\mathrm{GWh}]}\end{array}$ \\
\hline \multirow{3}{*}{ 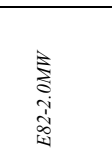 } & WT1 & 196 & 78 & 8.3 & 8.318 & 7.976 & 4.11 & \multirow{3}{*}{4.50} & \multirow{3}{*}{6.59} & \multirow{3}{*}{3.00} & \multirow{3}{*}{156.60} \\
\hline & WT2 & 166 & 78 & 7.53 & 7.238 & 6.979 & 3.59 & & & & \\
\hline & WT3 & 240 & 78 & 9.1 & 9.153 & 8.834 & 3.49 & & & & \\
\hline
\end{tabular}




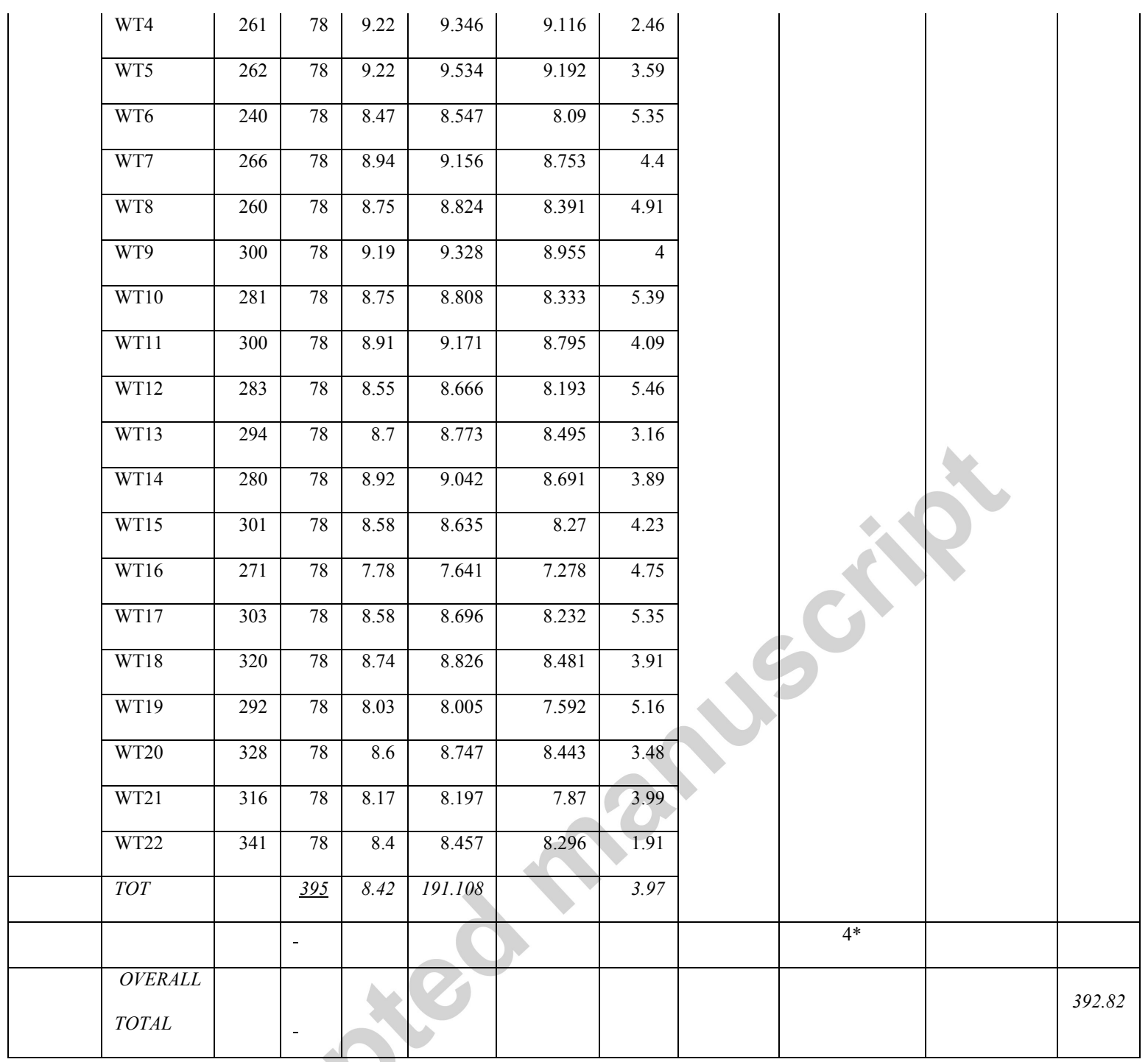

* Interconnection losses for the whole project

Table A2. RAE's estimation on the costs of High Voltage transmission Lines

\begin{tabular}{|c|c|}
\hline Type of High Voltage Line & Estimated Cost $(\mathbf{k} \in \mathbf{k m})$ \\
\hline $\mathrm{E} / 150 \mathrm{kV}$ (length at least $10 \mathrm{~km})$ & 75 \\
\hline $\mathrm{E} / 150 \mathrm{kV}$ (length at least $1.5 \mathrm{~km})$ & 110 \\
\hline $\mathrm{B} / 150 \mathrm{kV}$ (length at least $10 \mathrm{~km})$ & 100 \\
\hline $\mathrm{B} / 150 \mathrm{kV}$ (length at least $1.5 \mathrm{~km})$ & 145 \\
\hline $2 \mathrm{~B} / 150 \mathrm{kV}$ (length at least $10 \mathrm{~km})$ & 135 \\
\hline $2 \mathrm{~B} / 150 \mathrm{kV}$ (length at least $1.5 \mathrm{~km})$ & 195 \\
\hline
\end{tabular}




\begin{tabular}{|c|c|}
\hline B'B'/400 kV (length at least $10 \mathrm{~km}$ ) & 195 \\
\hline B'B'/400 kV (length at least $1.5 \mathrm{~km})$ & 270 \\
\hline 2B'B'/400 kV (length at least $10 \mathrm{~km})$ & 460 \\
\hline 2B'B'/400 kV (length at least $1.5 \mathrm{~km})$ & 240 \\
\hline B'B'B'/400 kV (length at least $10 \mathrm{~km})$ & 340 \\
\hline B'B'B'/400 kV (length at least $1.5 \mathrm{~km})$ & 500 \\
\hline $150 \mathrm{kV}$ (underground - single cable) & 850 \\
\hline $150 \mathrm{kV}$ (underground - double cable) & per case \\
\hline $150 \mathrm{kV}$ (submarine cable: $3+1$ backup cable) & \\
\hline
\end{tabular}

\section{Highlights}

- A detailed wind resource analysis of Kythira Island was implemented

- A Wind Farm Cash Flow Model was presented

- The analysis showed that only up to $122 \mathrm{MW}$ could be developed in the island

- The scenario of $112 \mathrm{MW}$ was found to be equally efficient as the $122 \mathrm{MW}$ one

- Indices were introduced to explicitly interpret the economic results 